\title{
Advances in Assessing the Severity of Atopic Dermatitis
}

\author{
Zheng-Hong Di, Li Zhang, Ya-Ni Lv, \\ Li-Ping Zhao, Hong-Duo Chen and Xing-Hua Gao \\ Department of Dermatology, No.1 hospital of China Medical University
}

China

\section{Introduction}

Atopic dermatitis (AD) is a chronic, relapsing and pruritic inflammatory skin disorder. The prevalence of $\mathrm{AD}$ has been increasing significantly in recent decades, especially in developed nations. The pathogenesis of $\mathrm{AD}$ is still not completely understood. AD may be the results of interactions of abnormalities of immune system, genetics, environment and epidermal barrier defects. There is a wide spectrum of clinical manifestations in AD. Accordingly, there have been a number of methods and laboratory markers to assess the severity of AD. In spite of the facts that various severity assessing criteria and laboratory markers were reported or, more or less, applied, owing to the complexity of disease, race differences and environmental uncertainties, there is disagreement about the definitions and clinical application of these criteria or markers. Nevertheless, easy and quick assessing severity methods for $\mathrm{AD}$ are required to guide both the daily clinical and research studies. Here, we describe some recent advances in the assessment of the severity of AD.

\subsection{Overview of the epidemiology of $A D$}

$\mathrm{AD}$ is a chronic, inflammatory, itchy condition that usually begins in infancy but may continue into adult life; the disease is genetically predisposed, and its expression is modified by environmental factors. The prevalence of AD is unevenly distributed worldwide, varying between $0.73-23 \%$ (Levy et al., 2003). There is a tendency of increased prevalence of AD in recent years, especially in developed industrial nations. For example, the prevalence of AD at the ages of 12-15 almost doubled in the last 20 years of 20th century in Japanese, suggesting the strong impact of environmental factors in AD development(Sugiura et al., 1998).The incidence of an infant to develop AD is $25 \%$ in three months after birth, or $50 \%$ in two years after birth, given that the mother is an AD sufferer; The incidence of AD in the offspring reaches as high as $79 \%$, if both the parents are atopic patients, suggesting the key role of genetic predisposition in the pathogenesis of $\mathrm{AD}$ (Bradley er al., 2000).Key clinical manifestations of AD include itchy, dry skin, inflammatory rashes and other atopic conditions. Though not fully clarified, the clinical phenotype characterizing AD is the product of interactions between susceptibility genes, the environment, defective skin barrier function, and immunologic responses. These complex interactions would induce biological and immunological responses at cellular or molecular levels, involving the skin, immune system or even the integument as a whole. 


\subsection{Diagnostic criteria of AD}

During the past decades about 10 diagnostic criteria for $\mathrm{AD}$ have been set up(Brenninkmeijer et al., 2008), while the Hanifin and Rajka diagnostic criteria(in 1980) and Williams diagnostic criteria(in 1994) are the two most widely used methods in the world(Roguedas et al., 2004). The H-R criteria is such a detailed one (4 major and 23 minor criteria) that it is time consuming and not easy to operate, and thus mainly suitable for investigative studies and impractical for epidemiologic studies. What's more, some of the minor features described in the criteria, such as anterior neck folds and the Dennie-Morgan infra-orbital fold, has been challenged for their diagnostic significance in a study on Swiss AD (Mevorah et al., 1988). The concise Williams criteria (1 mandatory and 5 major criteria), are suitable for clinical and epidemiological studies. Williams criteria has been extensively validated(Brenninkmeijer et al., 2008). Due to its inherent nature of easy operation, this diagnostic criterion could be recommended in future international studies. In 1995, International Study of Asthma and Allergies in Childhood (ISAAC) set up ISAAC questionnaire for prevalence survey of childhood $\mathrm{AD}$ (Asher et al., 1995).Taken together, an ideal diagnostic criteria need to be well-validated, easy to apply and suitable for interventional multicenter trials.

\section{Assessment of the disease severity in AD}

The methods of measuring disease severity of $\mathrm{AD}$ include the evaluation of lesion manifestations in combination with disease extent and intensity, subjective symptoms, quality of life (QOL), and the assessment of skin barrier function by bioengineering methods and laboratory parameters.

\subsection{Assessment of clinical scoring systems}

In the past, assessing the severity of $\mathrm{AD}$, at levels of either overall or individual parameters, was mostly dependant on clinical scoring systems, such as the Scoring Atopic Dermatitis index (SCORAD)( European Task Force on Atopic Dermatitis, 1993), Atopic Dermatitis Area and Severity Index score(ADASIS) (Bahmer, 1992), Eczema Area and Severity Index (EASI) (Hanifin, 2001), are the most widespread used methods, to name a few(Charman $\& W$ illiams, 2000).All of these tools, based on the entirely subjective score, have considerable inter-observer variability owing to the observers bias.

ADASIS was based on the lesion areas by point counting. On special body diagrams, the areas were color coded according to the severity of inflammation (green for mild, blue for moderate, and red for severe dermatitis). The result was evaluated by applying a transparent grid and fractionated lesion areas were weighted and multiplied by subjective pruritus intensity score. Haniffin et al suggested EASI index to assess the disease extent and percents of lesion area in four body regions (head and neck, lower limbs, upper limbs and trunk), borrowed from the psoriasis area and severity index (PASI) (Hanifin, 2001). The study by Rullo et al informed that EASI is more suitable for detection of subtle alterations of the severity of $\mathrm{AD}$ during drug effect studies, or follow-up of progression for research purposes (Rullo, 2008).

Charman and Williams evaluated 13 AD clinical scoring systems and confirmed that the simple and rapid SCORAD index was the most widely used one and its validity, reliability, sensitivity, and acceptability have been widely confirmed(Charman \&Williams, 2000).The 
SCORAD index includes objective symptoms (extent and intensity) and subjective criteria (daytime pruritus and sleep loss). The severity assessment of each items were evaluated at its average intensity. Due to that the subjective symptoms represented $20 \%$ of total of interobserver variation, European Task Force on Atopic Dermatitis recommended severity scale based only on the objective criteria of the SCORAD index to define mild, moderate, and severe AD (Kunz, 1997). It remains to be investigated that quite some laboratory parameters obtained from the lesion, serum, and other body fluids, have no significant correlation with SCORAD index. SCORAD index can not reflex the whole aspects of AD.

Most of the severity index has been applied for a given short-term therapeutic intervention, while they are insensitive in reflecting the overall disease activity to the chronic and fluctuating course of AD. Nottingham Eczema Severity Score (NESS) was introduced to be a clinical severity score method that documents $\mathrm{AD}$ severity over a long -term period of 12 months(Emerson et al., 2000; Hon et al., 2006).

For evaluating the life quality in AD, Quality of Life Index for Atopic Dermatitis (QoLIAD) is designed for adults with AD based on Quality of Life (QoL)and Children's Dermatology Life Quality Index (CDLQI) for children AD. These instruments could be used to evaluate the impact degree of AD and also measure the therapeutic effect (Whalley et al., 2004; BenGashir et al., 2004).

Taken together, though well recognized and widely applied, the implementation of various scoring systems is complicated and subject to a variety of bias. Noninvasive, objective measurement has been developed and in use in recent year. The objective severity assessment of atopic dermatitis system (OSAAD) (Sugarman et al., 2003), which take advantage of instrumentations to measure water content (stratum corneum hydration, $\mathrm{SCH}$ ), sebum content and trans-epidermal water loss (TEWL) of the skin, features the recent development of objective evaluation of AD.

OSAAD is a severity evaluation scale in AD including TEWL, SCH using a noninvasive bioengineering methods and estimation of affected body surface area (BSA). The method is suitable for both children and adults with AD compared with classical scoring system (Angelova-Fischer et al., 2005). The OSAAD score have several advantages over the clinical scoring methods. Measurement of TEWL and SCH is reproducible and reliable under given standard environment condition and instrument devices(Angelova-Fischer et al., 2005), able to evaluate quantitatively the severity scale of skin barrier impairment, sensitive to minor fluctuations in the course of $\mathrm{AD}$ development, and consequently applicable to assessment of treatment effects. The limitations of this technique are the inter- or intra- variability in AD patients, influenced by anatomic sites, environmental changes, etc. So the standardization of the conditions is very important in multicenter trials .There is no unified standard sites suitable for evaluation. Choi et al showed that antecubital fossa is the most favorable site for TEWL evaluation (Choi et al., 2003), while flexure surface is unsmooth. The ' $2 \mathrm{~cm}^{\prime}$ site under the antecubital fossa resembles a flexure and is conveniently flat for measurements (Hon et al., 2008).

\subsection{Evaluation of skin function and properties}

The skin barrier is primarily in the outer $15 \mu \mathrm{m}$ of the epidermis, the stratum corneum (SC) (Landmann, 1988). Breakdown of skin barrier is the primary event in the development of AD, which may result in atopic march (Lipozencic \& Wolf, 2007). The evaluation of skin barrier and properties is based on several variances: such as TEWL, natural moisturizing factors (NMF), skin sebum content, skin $\mathrm{pH}$ and skin hydration (SH). The study 
environment (controlled temperature and humidity level) of bioengineering research should be standardized.

From the skin surface, $\mathrm{SH}$ is relatively difficult to quantify objectively, instead, SCH level is measured .TEWL is a method to reflex $\mathrm{SH}$, and also correlated well with objective SCORAD score (Gupta et al., 2008). There are two main systems which have been used to measure TEWL by comparing water flux rate following titrated water application: open chamber and closed chamber. The main drawback of open-chamber systems is the disturbance of air movements. The closed-chamber systems conquers this limitation by its closed-chamber, but a major problem with it is that it can not be used to perform continuous measurement, as there is a need of cleaning water vapor of the chamber after a site reading. Elkeeb et al introduced a new closed-chamber systems with a condenser to remove water vapor from chamber and enabling continuous measurement and confirmed significantly correlated with conventional closed and open-chamber systems(Elkeeb et al., 2010) .Later agreed standards of TEWL calibration method is needed to improve the comparability of TEWL measurement devices supplied by different manufacturers.

NMF is the most important factor for maintaining the skin proper moisture levels in SC. NMF largely comes from the acid degradation products of filaggrin, including pyrrolidone carboxylic acid (PCA) and urocanic acid (UCA), which also contribute to skin hydration acid mantle in outer SC (O'Regan et al., 2009). While lowered expression of FLG in AD lesion was found universally (Howell et al., 2009), the loss-of-function mutations of FLG were observed in only less one-third of the general AD population (Marenholz et al., 2006; Palmer et al., 2006; Zhang et al., 2011; Ma et al., 2010). Reduced NMF levels were independently associated with FLG genotype and is a general feature of AD (Kezic et al., 2010).HighPerformance Liquid Chromatograph (HPLC) is the common method used to evaluate NMF (Robinson et al., 2010a; Robinson et al., 2010b ).

The skin surface sebum content, hydration and $\mathrm{pH}$ can be check by several commercialized instruments with respective probes on the surface of skin (Choi et al., 2003; Firooz et al., 2007; Man et al., 2009). They are easy to operate, but time consuming, difficult to use in infant AD patients. The temperature and humidity levels during their application also should be standardized.

\subsection{Laboratory tests}

Laboratory tests may also be applied for AD.

\subsubsection{Skin tests (atopy patch test/ APT, skin prick test /SPT)}

APT was traditionally used to assess sensitization to inhalant. Allergens/aeroallergen as a skin test, was used to diagnose AD (Ring et al., 1997).An eczematous reaction based on T cell-specific delayed-type allergic response to the allergens on the healthy skin of the patient's back or forearm is read after 48 and 72 hours. There is no golden standard for aeroallergen provocation of AD. Although the kinds of allergens are different in patients of different environment, race, and regions, the European APT model with standardization of allergen concentration and vehicle may be an useful diagnostic tool to AD patients. However, the clinical relevance of positive APT reactions depends on standardized provocation and avoidance testing verification (Lipozencic \& Wolf, 2010).

Although the double-blind, placebo-controlled oral food challenges (DBPCFC) is the golden standard of diagnosis in food allergy(Sampson, 2003). The test is not always suitable to 
interpret and operate, particularly in patients sensitive to several kinds of food or potential to anaphylactic Shock. Skin prick test (SPT) is designed for diagnosing food immediate hypersensitivity(Isolauri \& Turjanmaa, 1996).The APT reflect delayed-phase allergic reactions, even with a late onset of symptoms (more than 2 hours after food ingestion). APT may provide further diagnostic information in addition to the SPT and serum IgE values used with standardized allergen concentration and vehicle (Niggemann et al., 2005). APT has higher sensitivity than SPT test for food allergy in young children with AD, and can be used to supplement the SPT in diagnosing food allergy in AD children(Stromberg, 2002) and those with late reactions were more easily to have positive APT tests to the relevant foods (Saarinen et al., 2001).The combination of APT, SPT and serum-specific IgE reduce the need for oral food challenges in children with AD (Roehr et al., 2001) and significantly enhance the accuracy in the diagnosis of food allergy when the total $\operatorname{IgE}$ is normal or SPT is negative(Boissieu\&Dupont,2003). APT test may also help among children with AD to prevent unnecessary restrictive diets (Niggemann et al., 2000). While in a study of allergy to cow's milk and hen's egg in 3 year- old children, no hypersensitivity to cow's milk or hen's egg was predicted by APT alone. The real value of the APT in food allergy in children need to be further studied(Osterballe et al., 2004).

The sensitivity and specificity of the SPT of food allergen was 58\% and $70 \%$, while the sensitivity and specificity of the APT for late-phase clinical reactions of food allergen was $76 \%$ and $95 \%$ respectively (Niggemann et al., 2000). The negative predictive value is over $95 \%$, while the positive predictive value is less than $40 \%$ of SPT (Sampson, 2003).So, a positive skin test cannot completely confirm a clinical food hypersensitivity, while a negative result can virtually rules out some kind of IgE-mediated food allergy. It should be noted that SPT may remain positive for many years after the loss of clinical food allergic reactivity. Patients should be re-challenged at intervals to determine whether their food allergy persists (egg, every 2-3 years; milk, soy, wheat, peanut, nuts, fish, and shellfish, every 1-2 years) (Sampson, 2001).

\subsubsection{Biomarkers in serum or other body fluid}

Seeking biomarkers in serum or other body fluid to reflect the severity of AD is an interesting topic. Though the fact that serum IgE level is elevated in more than half of AD has been well established, its correlation with disease severity is disputed, so was the interpretation for peripheral blood eosinophil count, which could be affected by many other factors except for hypersensitivity, such as parasite, drugs, hormone. There were reports that urine eosinophil protein X (Jenerowicz et al., 2006) and leukotriene E4 (Hon et al., 2004) may be used as biomarkers to reflect the severity of AD. Recently, Urinary aquaporin-2 was found to positively correlate with skin dryness of infant AD (Di et al., 2010). The clinical manifestations and distribution pattern of AD may vary at different age-related stages. AD is most prevalent in infants. An objective, easy and non-invasive test for evaluation of infant $\mathrm{AD}$ and corresponding management is much expected by both healthcare workers and parents.

\subsubsection{Serum total IgE, specific IgE and IgE autoantibodies}

IgE and specific IgE (ELISA or Radioallergosorbent test/RAST) can be used without the need of preparing lesion-free skin and waiting-up of antihistamines drug withdrawal, it is more practical than SPT for the screening of food allergies in most office settings due to its quick and easy- to operate merit. Serum IgE levels are increased in about $80 \%$ of adult AD 
(C.A.Akdis et al., 2006). The remaining 20\%-30\% of patients exhibiting normal serum IgE levels and lack allergen-specific sensitization, are classified as intrinsic AD (IAD) (Novak \&Bieber, 2003; Boguniewicz et al., 2006). 28\% of AD serum contains IgE autoantibodies which target keratinocytes in AD patients (Altrichter et al., 2008).

For the total IgE and specific IgE, similar to skin tests, a negative result is fairly reliable in ruling out an IgE-mediated reaction. For a positive result, although the lesions significantly regress, there maybe no parallel decrease of serum IgE level. Further large-scale investigations of serum IgE levels between patients with extrinsic atopic dermatitis and intrinsic atopic dermatitis are needed (Ott et al., 2009).

\subsubsection{Mast cell, eosinophil and its cellular contents}

Mast cells play a very important role in the pathogenesis of AD. Tryptase and chymase are the major compound of mast cell granules. They have various effects on angiotensin, metalloproteases, lipoproteins, procollagen, neuropeptides and cytokines. The study by Badertscher et al confirmed that mast cell chymase is increased in chronic atopic dermatitis lesion (Badertscher et al., 2005), while there was no correlation of serum tryptase level with the severity of AD (Gerdes et al., 2009).

Eosinophils play an important role in inflammatory process of AD, the activated eosinophils release granule proteins including eosinophil cationic protein (ECP) and eosinophil derived neurotoxin/eosinophil protein $\mathrm{X}(\mathrm{EDN} / \mathrm{EPX})$. ECP is released from activated eosinophils during the inflammation process. Serum ECP level increased in children with AD (Badertscher et al., 2005; Damps-Konstanska et al., 2005), but there was no correlation with the SCORAD index (Wu et al., 2011). While a study by Selnes et al suggest that there is no association between serum ECP and AD in an unselected population of children (Selnes \&Dotterud,2005).Several investigative evidence indicate that serum EDN may reflect the disease severity in childhood phase $\mathrm{AD}$ (Taniuchi et al., 2001; Lee et al.,2009) and correlated with SCORAD index (K.Y.Lee et al.,2009).

\subsubsection{T Lymphocytes and their subsets in peripheral blood}

For a long time, two main types of effector CD4+ T cells, named as type $1 \mathrm{~T}$ helper (Th1) and type 2 Th (Th2) respectively, have been thought to be deeply involved in AD. Th2 cells produce IL-4, IL-5 and IL-13, Th1 cells produce interferon (IFN)- $\gamma$ as the main cytokines. $\mathrm{AD}$ is an inflammatory skin disease characterized by the predominant infiltration of T cells, eosinophils, mast cell, dendric cell (DC) and macrophages in lesions. Disequilibrium between Th1/Th2 lymphocytes is an important feature of AD. Typically, $\mathrm{AD}$ has been considered the paradigm of a Th2-mediated disease, characterized by increase of Th2 and decrease of Th1 and their cytokines level in peripheral blood. Recently, research efforts have resulted in new subgroups of CD4+ T cells, such as IL-17producing Th cells (Th17), the main cytokine they produce is IL-17A, and T-regulatory (Treg) ( Agrawal et al., 2011; Souwer er al., 2010). There are two main groups of Treg cells identified. One is the natural Treg cells, characterized by CD4+CD25+ phenotype and develops under the control of the transcription factor FoxP3. The other is the adaptive Treg or T-regulatory type 1 (Tr1), characterized by the secretion of high levels of IL-10(M. Akdis et al., 2004; C.A.Akdis et al., 1998). It is suggested that the onset of allergic diseases are partly caused by insufficient development of allergen-specific Tregs. FoxP3+Treg could be found in the perivascular, dermis interstitial, and the dermoepidermal junction and the basal and suprabasal epidermal layers of AD (Caproni et al., 2007). But the study 
by Hayashida et al indicated that FoxP3+Treg subsets was similar to that of normal controls in peripheral blood of the acute phase $\mathrm{AD}$ and the decreased number of circulating Th17 cells is negatively correlated with CCL17, IgE and eosinophil levels in AD patients (Hayashida et al., 2011). IL-17 has been identified in acute AD lesions (Toda et al., 2003). The exact role of Treg and Th17 cell in AD is still unclear.

\subsubsection{Cytokines and chemokine in the serum}

A complex network of cytokines and chemokines are involved in atopic inflammation, at both the starting and maintainance stages of the inflammation. Scratching injury induce the production of proinflammatory cytokines (such as IL-1, TNF-a, GM-CSF), which in turn induce CCL27 and CCL17 development. Subsequently, CCL27 and CCL17 recruit skinhoming memory $\mathrm{T}$ cells into the skin. Within the skin, $\mathrm{T}$ cells are activated and release effector cytokines (eg, IL-4, IL-5, IL-13 in acute phase lesion, or IFN-r in the chronic lesion of $\mathrm{AD}$ ).These effector cytokines will sustain and amplify the production of chemokines within atopic skin. In this complex procedure, many chemokines, (such as CCL1, CCL2, CCL11, CCL13, CCL18, CCL20, CCL21, and CCL26) interact with various immune effector cells through their receptors(D.Y.Leung et al., 2004; Homey et al., 2006). AD is a disease with the participation of whole body immune system, and that the immunologic abnormality is not limited to the skin. Generally, as is widely accepted that AD has been considered the paradigm of a Th2-mediated disease, characterized by increase Th2 and decrease Th1 and cytokines level, elevated serum IgE levels, eosinophilia in peripheral blood. Recent researched showed that the severity of $\mathrm{AD}$ has also been found to be associated with the levels of various other cytokines and chemokines in the lesion and serum, in addition to the conventional serum parameters, such as total serum IgE (tIgE), eosinophilic cationic protein (ECP), increased T helper type 2 (Th2)-skewed cytokine patterns(IL4,13) and decreased IFN$\gamma$. Some of them in the serum of AD are correlated with disease severity, and thus may be new biomarkers to reflect $\mathrm{AD}$ disease severity. Clinical trials on interleukins and chemokines in the serum of patients with AD were summarized, in table1 and table 2.

\section{Interleukin/IL}

Many interleukins participate in AD and it is a consensus that increased IL4, 13 levels are seen in the serum of AD. Recently, many of other interleukins have been shown to play roles in the pathogenesis of $\mathrm{AD}$, and increased serum levels have been detected (in table1). IL-10 is a powerful Th2 cytokines produced by LC in the lesion of AD and exerts its function through inhibition of the secretion of Th1 cytokines. While, the level of IL-10 in the serum may be not a significant marker (Shin et al., 2005). IL-22, a member of the IL-10 family and known to be preferentially produced by Th17 cells, is increased and has significant correlation with CCL17 levels in the serum of AD patients (Hayashida et al., 2011). On the contrary, IL-12 is prominently expressed in the chronic lesion of AD, it is a powerful inducer of Th0 to Th1 conversion and subsequent IFN- $\gamma$ secretion from Th1.The level of IL-12 in the serum of $\mathrm{AD}$ is controversially reported. Piancatelli et al confirmed the serum IL-12 levels increased in paediatric AD (Piancatelli et al., 2008), while the study by Aral, M et al showed that there was no statistically significant difference between children $\mathrm{AD}$ and controls in respect of serum levels of IL-12(Aral et al., 2006). IL-16 is a natural ligand of CD4 molecules. Besides its chemotactic properties to CD4-expressing cells, IL-16 amplifies inflammatory processes and possesses immunoregulatory functions (Mathy et al., 2000; Nagy et al., 2011). IL-16 was found to be increased in the serum of AD, both in child and adult patients (Nagy 
et al., 2011; Belloni Fortina et al., 2006; Masuda et al., 2003).Also ,the level of IL-16 in the serum was significantly correlated with serum total IgE(Nagy et al., 2011), but not correlated with SCORAD index(Belloni Fortina et al., 2006) and eosinophils counting in peripheral blood(Nagy et al., 2011).The finding of Masuda K. et al confirmed IL-16 level in serum was significantly higher in patients with $\mathrm{AD}$, and decreased significantly after topical treatment with corticosteroids or tacrolimus (Masuda et al., 2003). IL-18 is a pleiotropic cytokine that works both in Th1 and Th2 lymphocyte-mediated immunity. As a member of the IL-1 super family, IL-18 is a potent inducer of IFN- $\gamma$. IL-18 is involved in the pathogenesis of AD including Th1 and Th2 T lymphocyte-mediated immunity, including cytokine accumulation, and increase of IgE and histamine levels. Increased serum level of IL-18 and correlation with disease severity, eosinophil counts and serum sIL-2R levels was reported in several researches both in adult and children patients (Aral et al., 2006; Yoshizawa et al., 2002; Park \&Youn, 2007; Sohn et al., 2004; Hon et al., 2004). IL-31 is a Th derived cytokine. Serum IL-31 was found over-expressed in both adults and paediatric AD and its serum level correlated positively with the disease severity (Raap et al., 2008; Ezzat et al., 2011).

\section{Chemokines their receptors}

Little is known about the very early events of atopic skin inflammation. The unceasing amplification inflammation cycle in AD lesions might start with pruritus and the injury induced by scratching, and skin barrier disruption, resulting in proinflammatory cytokine

\begin{tabular}{|c|c|c|c|c|}
\hline $\begin{array}{l}\text { Interle- } \\
\text { ukins }\end{array}$ & $\begin{array}{l}\text { Correlation with other } \\
\text { clinical parameters }\end{array}$ & References & $\begin{array}{l}\text { Expression in } \\
\text { serum }\end{array}$ & $\begin{array}{l}\text { Age of studied } \\
\text { populations }\end{array}$ \\
\hline IL-2 & $\begin{array}{l}\text { Inverse correlation with } \\
\text { serum IgE }\end{array}$ & $\begin{array}{l}\text { Yoshizawa } \\
\text { et al., } 2002\end{array}$ & Increase & $\begin{array}{l}\text { Adult } \\
\text { (13-43years) }\end{array}$ \\
\hline \multirow[t]{3}{*}{ IL-12 } & $\begin{array}{l}\text { Negative correlation with } \\
\text { age and positive with } \\
\text { SCORAD index }\end{array}$ & $\begin{array}{l}\text { Piancatelli } \\
\text { et al., } 2008\end{array}$ & Increase & $\begin{array}{l}\text { Paediatric AD } \\
\text { (1-184months) }\end{array}$ \\
\hline & $\begin{array}{l}\text { Positive correlation with } \\
\text { SCORAD }\end{array}$ & $\begin{array}{l}\text { Aral et al., } \\
2006\end{array}$ & $\begin{array}{l}\text { No different } \\
\text { with controls. }\end{array}$ & 5-12 year old \\
\hline & $\begin{array}{l}\text { Positive correlation with } \\
\text { IL-10 }\end{array}$ & $\begin{array}{l}\text { Yoshizawa } \\
\text { et al., } 2002\end{array}$ & Increase & $\begin{array}{l}\text { Adult } \\
\text { (13-43years) }\end{array}$ \\
\hline \multirow[t]{3}{*}{ IL-16 } & $\begin{array}{l}\text { Positive correlation with } \\
\text { serum total IgE }\end{array}$ & $\begin{array}{l}\text { Nagy et al., } \\
2011\end{array}$ & Increase & $\begin{array}{l}\text { Mean : } 18.6 \text { years; } \\
\text { range: } 7-49 \text { years }\end{array}$ \\
\hline & $\begin{array}{l}\text { No correlation with } \\
\text { SCORAD index }\end{array}$ & $\begin{array}{l}\text { Belloni } \\
\text { Fortina et al., } \\
2006\end{array}$ & Increase & Children \\
\hline & $\begin{array}{l}\text { Positive correlation with } \\
\text { eosinophil count in } \\
\text { peripheral blood and } \\
\text { SCORAD }\end{array}$ & $\begin{array}{l}\text { Masuda et al., } \\
2003\end{array}$ & Increase & $\begin{array}{l}\text { Adult: } \\
\text { aged } 14-52 \text { years, } \\
\text { median } 22\end{array}$ \\
\hline IL-18 & Not done & $\begin{array}{l}\text { Narbutt et al., } \\
2009\end{array}$ & $\begin{array}{l}\text { Decrease under } \\
10 \text { years, no } \\
\text { difference over } \\
10 \text { years }\end{array}$ & $\begin{array}{l}\text { Mean age } 11.4 \\
\text { years with } \\
\text { moderate } \mathrm{AD}\end{array}$ \\
\hline
\end{tabular}




\begin{tabular}{|c|c|c|c|c|}
\hline \multirow[t]{6}{*}{$\begin{array}{l}\text { Interle- } \\
\text { ukins }\end{array}$} & $\begin{array}{l}\text { Correlation with other } \\
\text { clinical parameters }\end{array}$ & References & $\begin{array}{l}\text { Expression in } \\
\text { serum }\end{array}$ & $\begin{array}{l}\text { Age of studied } \\
\text { populations }\end{array}$ \\
\hline & $\begin{array}{l}\text { Positive correlation with } \\
\text { SCORAD index }\end{array}$ & $\begin{array}{l}\text { Park et al., } \\
2007\end{array}$ & Increase & $\begin{array}{l}15 \pm 10 \text { years; } \\
\text { range:2-41years }\end{array}$ \\
\hline & $\begin{array}{l}\text { Positive correlation with } \\
\text { SCORAD index }\end{array}$ & $\begin{array}{l}\text { Aral et al., } \\
2006\end{array}$ & Increase & 5-12 year old \\
\hline & $\begin{array}{l}\text { Higher in sever AD than in } \\
\text { mild AD }\end{array}$ & $\begin{array}{l}\text { Sohn et al., } \\
2004\end{array}$ & Increase & $\begin{array}{l}\text { Age range, } \\
9 \text { months to } 11 \\
\text { years; mean, } 4.28 \pm \\
2.8 \text { years }\end{array}$ \\
\hline & $\begin{array}{l}\text { Positive correlation with } \\
\text { SCORAD index }\end{array}$ & $\begin{array}{l}\text { Hon et al., } \\
2004\end{array}$ & Increase & $\begin{array}{l}\text { Median age of } \\
2.2 \text { years } \\
\text { (interquartile } \\
\text { range } 0.7-4.6 \\
\text { years) }\end{array}$ \\
\hline & $\begin{array}{l}\text { Positive correlation with } \\
\text { eosinophil counts and serum } \\
\text { soluble IL-2 receptor }\end{array}$ & $\begin{array}{l}\text { Yoshizawa } \\
\text { et al., } 2002\end{array}$ & Increase & $\begin{array}{l}\text { Adult } \\
\text { (13-43years) }\end{array}$ \\
\hline IL-22 & $\begin{array}{l}\text { Positive correlation with } \\
\text { CCL17 }\end{array}$ & $\begin{array}{l}\text { Hayashida } \\
\text { et al., } 2011\end{array}$ & Increase & $\begin{array}{l}\text { Adults (mean } \pm S D \\
\text { age;27.2 } \pm 6.1 \text { years ) }\end{array}$ \\
\hline \multirow[t]{2}{*}{ IL-31 } & $\begin{array}{l}\text { Positive correlation with } \\
\text { LSS, SSS and SCORAD } \\
\text { index }\end{array}$ & $\begin{array}{l}\text { Ezzat et al., } \\
2011\end{array}$ & Increase & $\begin{array}{l}\text { Ages ranged } \\
\text { between } 1 \text { and } 10 \\
\text { years (mean } \pm \text { SD: } \\
5.75 \pm 2.11 \text { years) }\end{array}$ \\
\hline & $\begin{array}{l}\text { Positive correlation with } \\
\text { SCORAD index both in } \\
\text { extrinsic AD and intrinsic } \\
\text { AD }\end{array}$ & $\begin{array}{l}\text { Raap et al., } \\
2008\end{array}$ & Increase & $\begin{array}{l}\text { Extrinsic AD } \\
\text { (mean age, } \\
37.8 \pm 14.1 \text { years); } \\
\text { Intrinsic AD } \\
\text { (mean age, } \\
31.8 \pm 11.2 \text { years) }\end{array}$ \\
\hline
\end{tabular}

Table 1. Literatures about serum interleukins in AD

\begin{tabular}{|c|c|c|c|c|}
\hline $\begin{array}{l}\text { Chemo- } \\
\text { kine }\end{array}$ & $\begin{array}{l}\text { Correlation with other } \\
\text { clinical parameters }\end{array}$ & References & $\begin{array}{l}\text { Expressions in } \\
\text { serum }\end{array}$ & $\begin{array}{l}\text { Adult / childhood } \\
\text { /infant phase }\end{array}$ \\
\hline CXCL9 & Not done & $\begin{array}{l}\text { Narbutt et al., } \\
2009\end{array}$ & $\begin{array}{l}\text { Decrease under } \\
10 \text { years old }\end{array}$ & $\begin{array}{l}\text { Children (mean } \\
\text { age } 11.4 \text { years } \\
\text { with moderate AD }\end{array}$ \\
\hline \multirow[t]{2}{*}{$\begin{array}{l}\text { CXCL10/ } \\
\text { IP-10 }\end{array}$} & Not done & $\begin{array}{l}\text { Narbutt et al., } \\
2009\end{array}$ & $\begin{array}{l}\text { Decrease under } \\
10 \text { years old }\end{array}$ & $\begin{array}{l}\text { Children (mean } \\
\text { age } 11.4 \text { years } \\
\text { with moderate AD }\end{array}$ \\
\hline & $\begin{array}{l}\text { Did not correlate with } \\
\text { SCORAD index and its } \\
\text { extend and intensity }\end{array}$ & $\begin{array}{l}\text { T.F.Leung } \\
\text { et al., } 2003\end{array}$ & $\begin{array}{l}\text { No difference } \\
\text { between mild } \\
\text { and moderate } \\
\text { AD }\end{array}$ & $\begin{array}{l}\text { Median } 2.1 \text { years, } \\
\text { range } 0.6-4.2 \text { years }\end{array}$ \\
\hline
\end{tabular}




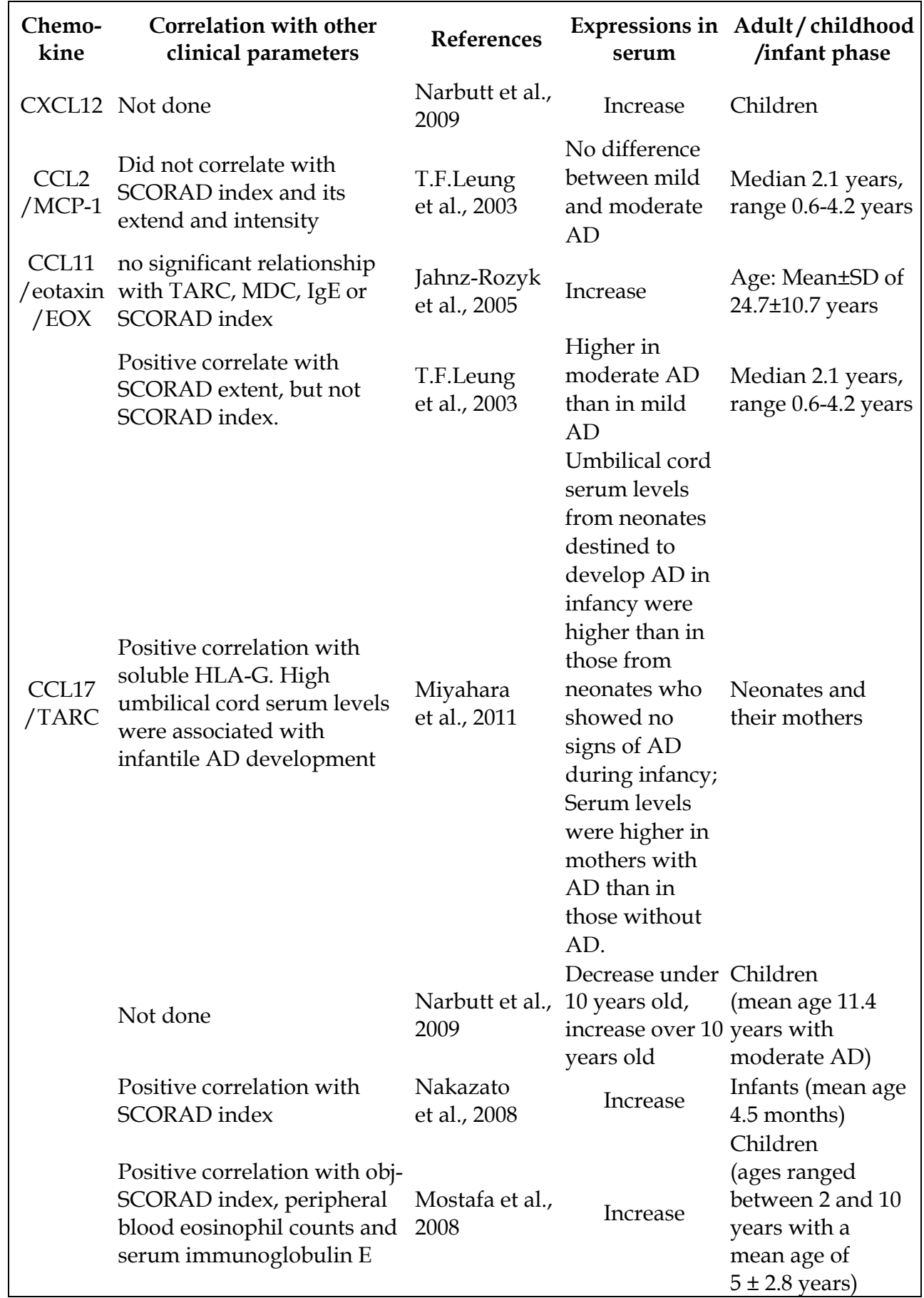




\begin{tabular}{|c|c|c|c|c|}
\hline $\begin{array}{l}\text { Chemo- } \\
\text { kine }\end{array}$ & $\begin{array}{l}\text { Correlation with other } \\
\text { clinical parameters }\end{array}$ & References & $\begin{array}{c}\text { Expressions in } \\
\text { serum }\end{array}$ & $\begin{array}{l}\text { Adult / childhood } \\
\text { /infant phase }\end{array}$ \\
\hline & $\begin{array}{l}\text { Positive correlation with } \\
\text { SCORAD index }\end{array}$ & $\begin{array}{l}\text { Hon et al., } \\
2007\end{array}$ & Increase & $\begin{array}{l}\text { Aged younger } \\
\text { than } 18 \text { years } \\
\text { (mean } \pm S D \text { : } \\
10.7 \pm 4.4 \text { years) }\end{array}$ \\
\hline & $\begin{array}{l}\text { Positive correlation with } \\
\text { serum CTACK and SCORAD } \\
\text { index; decreased in } \\
\text { accordance with ages }\end{array}$ & $\begin{array}{l}\text { Song et al., } \\
2006\end{array}$ & Increase & $\begin{array}{l}\text { Children } \\
(4.9 \pm 3.3 \text { years, } \\
2 \text { months to } \\
14 \text { years })\end{array}$ \\
\hline & $\begin{array}{l}\text { Positive correlation with } \\
\text { SCORAD index }\end{array}$ & $\begin{array}{l}\text { Jahnz-Rozyk } \\
\text { et al., } 2005\end{array}$ & Increase & $\begin{array}{l}\text { Age (Mean } \pm S D \text { of } \\
24.7 \pm 10.7 \text { years) }\end{array}$ \\
\hline & $\begin{array}{l}\text { Positive correlation with } \\
\text { SCORAD extent and } \\
\text { intensity components, } \\
\text { Positive correlation with } \\
\text { CCL22, but not SCORAD } \\
\text { index } \\
\text { Correlation with eosinophil } \\
\text { number, SCORAD index, } \\
\text { serum sE-selectin and } \\
\text { weakly correlated with } \\
\text { serum sIL-2 receptor }\end{array}$ & $\begin{array}{l}\text { T.F.Leung } \\
\text { et al., } 2003\end{array}$ & $\begin{array}{l}\text { No different } \\
\text { between mild } \\
\text { and moderate } \\
\text { AD }\end{array}$ & $\begin{array}{l}\text { Median } 2.1 \text { years } \\
\text { range } 0.6-4.2 \text { years }\end{array}$ \\
\hline $\begin{array}{l}\text { CCL22 } \\
\text { /MDC }\end{array}$ & Not done & $\begin{array}{l}\text { Narbutt et al., } \\
2009\end{array}$ & $\begin{array}{l}\text { Increase over } \\
10 \text { years old }\end{array}$ & $\begin{array}{l}\text { Children (mean } \\
\text { age } 11.4 \text { years } \\
\text { with moderate AD }\end{array}$ \\
\hline & $\begin{array}{l}\text { Positive correlation with } \\
\text { SCORAD index }\end{array}$ & $\begin{array}{l}\text { Nakazato } \\
\text { et al., } 2008\end{array}$ & Increase & $\begin{array}{l}\text { Infants (mean age } \\
4.5 \text { months) }\end{array}$ \\
\hline & $\begin{array}{l}\text { Positive correlation with obj- } \\
\text { SCORAD index, peripheral } \\
\text { blood eosinophil counts and } \\
\text { serum immunoglobulin E }\end{array}$ & $\begin{array}{l}\text { Mostafa et al., } \\
2008\end{array}$ & Increase & $\begin{array}{l}\text { Children } \\
\text { (ages ranged } \\
\text { between } 2 \text { and } 10 \\
\text { years with a mean } \\
\text { age of } 5 \pm 2.8 \\
\text { years) }\end{array}$ \\
\hline & $\begin{array}{l}\text { Positive correlation with } \\
\text { SCORAD index }\end{array}$ & $\begin{array}{l}\text { Jahnz-Rozyk } \\
\text { et al., } 2005\end{array}$ & Increase & $\begin{array}{l}\text { Age: Mean } \pm \text { SD of } \\
24.7 \pm 10.7 \text { years }\end{array}$ \\
\hline & $\begin{array}{l}\text { Positive correlation with } \\
\text { SCORAD index and its } \\
\text { extent and intensity } \\
\text { components, Positive } \\
\text { correlation with CCL17 }\end{array}$ & $\begin{array}{l}\text { T.F.Leung } \\
\text { et al., } 2003\end{array}$ & $\begin{array}{l}\text { Higher in } \\
\text { moderate AD } \\
\text { than in mild } \\
\text { AD }\end{array}$ & $\begin{array}{l}\text { Median } 2.1 \text { years } \\
\text { range } 0.6-4.2 \text { years }\end{array}$ \\
\hline & $\begin{array}{l}\text { Positively related with } \\
\text { SCORAD index, serum sE- } \\
\text { selectin, sIL-2R, TARC and } \\
\text { eosinophil numbers in } \\
\text { peripheral blood }\end{array}$ & $\begin{array}{l}\text { Kakinuma } \\
\text { et al., } 2002\end{array}$ & Increase & Not described \\
\hline
\end{tabular}




\begin{tabular}{|c|c|c|c|c|}
\hline $\begin{array}{l}\text { Chemo- } \\
\text { kine }\end{array}$ & $\begin{array}{l}\text { Correlation with other } \\
\text { clinical parameters }\end{array}$ & References & $\begin{array}{l}\text { Expressions in } \\
\text { serum }\end{array}$ & $\begin{array}{l}\text { Adult / childhood } \\
\text { /infant phase }\end{array}$ \\
\hline $\begin{array}{l}\text { CCL26 } \\
\text { /eotaxin- } \\
3\end{array}$ & $\begin{array}{l}\text { Positive correlation with the } \\
\text { serum CCL17,CCL22 levels, } \\
\text { eosinophil numbers in } \\
\text { peripheral blood and } \\
\text { SCORAD index }\end{array}$ & $\begin{array}{l}\text { Kagami et al., } \\
2003\end{array}$ & Increase & $\begin{array}{l}\text { Adult }(\text { mean } \pm S D: \\
28 \cdot 7 \pm 7 \cdot 1 \text { years })\end{array}$ \\
\hline \multirow[t]{6}{*}{$\begin{array}{l}\text { CCL27 } \\
\text { /CTACK }\end{array}$} & Not done & $\begin{array}{l}\text { Narbutt et al., } \\
2009\end{array}$ & $\begin{array}{l}\text { Increase under } \\
10 \text { years old }\end{array}$ & $\begin{array}{l}\text { Children (mean } \\
\text { age } 11.4 \text { years } \\
\text { with moderate AD }\end{array}$ \\
\hline & $\begin{array}{l}\text { Positive correlation with } \\
\text { SCORAD index }\end{array}$ & $\begin{array}{l}\text { Nakazato } \\
\text { et al., } 2008\end{array}$ & Increase & $\begin{array}{l}\text { Infants (mean age } \\
4.5 \text { months) }\end{array}$ \\
\hline & $\begin{array}{l}\text { Positive correlation with } \\
\text { SCORAD index }\end{array}$ & $\begin{array}{l}\text { Hon et al., } \\
2007\end{array}$ & Increase & $\begin{array}{l}\text { Aged younger } \\
\text { than } 18 \text { years } \\
\text { (mean } \pm \text { SD: } \\
10.7 \pm 4.4 \text { ) }\end{array}$ \\
\hline & $\begin{array}{l}\text { Positive correlation with } \\
\text { their serum TARC; SCORAD } \\
\text { index; decreased in } \\
\text { accordance with their ages }\end{array}$ & $\begin{array}{l}\text { Song et al., } \\
2006\end{array}$ & Increase & $\begin{array}{l}\text { Children: } \\
4.9 \pm 3.3 \text { years, } \\
2 \text { months to } \\
14 \text { years }\end{array}$ \\
\hline & $\begin{array}{l}\text { Positive correlated with } \\
\text { SCORAD index }\end{array}$ & $\begin{array}{l}\text { Hon et al., } \\
2004\end{array}$ & Increase & $\begin{array}{l}\text { Children: median } \\
\text { age of } 5 \text { (range: } \\
1-11 \text { years) }\end{array}$ \\
\hline & $\begin{array}{l}\text { Positive correlation with } \\
\text { SCORAD index, sIL-2 } \\
\text { receptor, sE-selectin,TARC, } \\
\text { MDC in serum }\end{array}$ & $\begin{array}{l}\text { Kakinuma } \\
\text { et al., } 2003\end{array}$ & Increase & $\begin{array}{l}\text { Adult(mean } \pm \\
\text { SEM age, } \\
28.5 \pm 6.8 \text { years })\end{array}$ \\
\hline \multirow[t]{2}{*}{$\begin{array}{l}\text { CCL28/ } \\
\text { MEC }\end{array}$} & $\begin{array}{l}\text { Positive correlation with LSS } \\
\text { and SCORAD index, } \\
\text { peripheral eosinophil counts, } \\
\text { and serum LDH }\end{array}$ & $\begin{array}{l}\text { Ezzat et al., } \\
2009\end{array}$ & Increase & $\begin{array}{l}\text { Ages ranged } \\
\text { between } 8 \text { and } 120 \\
\text { months } \\
\text { (mean } \pm \text { SD: } 47 \pm \\
22 \text { months) }\end{array}$ \\
\hline & Not done & $\begin{array}{l}\text { Kagami et al., } \\
2005\end{array}$ & Increase & $\begin{array}{l}\text { Adults(mean } \pm S D: \\
28.7 \pm 6.7 \text { years) }\end{array}$ \\
\hline $\begin{array}{l}\text { CX3CL1 } \\
\text { /fracta- } \\
\text { lkine }\end{array}$ & $\begin{array}{l}\text { Positively associated with } \\
\text { the scoring system proposed } \\
\text { by Rajka and Langeland. }\end{array}$ & $\begin{array}{l}\text { Echigo et al., } \\
2004\end{array}$ & Increase & $\begin{array}{l}\text { Age: } 24.7 \pm 7.4 \\
\text { years }\end{array}$ \\
\hline
\end{tabular}

Table 2. Literatures about serum chemokines in AD. Abbreviations used in the table: CXCL10/IP-10, IFN-induced protein of $10 \mathrm{kd}$; CCL2/MCP-1, monocyte chemotactic protein 1; CCL11 / eotaxin (EOX); CCL17/TARC, thymus and activation-regulated chemokine; CCL22/MDC, macrophage-derived chemokine; CCL26/eotaxin-3; CCL27/CTACK, cutaneous T cell-attracting chemokine; CCL28/MEC, Mucosa-associated epithelial chemokine; CX3CL1/fractalkine; sE-selectin, serum soluble E-selectin; sIL-2R, soluble interleukin-2 receptor. 
and chemokine production, directing the recruitment of pathogenic leukocytes to the skin (Steinhoff et al., 2006). There are many researches conformed that they are useful inflammatory markers for assessing severity of $\mathrm{AD}$. Chemokines attract leukocytes transmigrate into the skin in $\mathrm{AD}$ by their gradients directing. Chemokine ligand-receptor interactions direct the multistep process of leukocyte migration. Chemokines can be classed into 4 subclasses according to the arrangement of $\mathrm{N}$-terminal cysteine residues: CXC chemokines (CXCL); CC chemokines (CCL); $\mathrm{C}$ chemokines (XCL), and CX3C chemokine (CX3CL). To date, 45 human chemokine ligands and $10 \mathrm{CC}$ chemokine, 7 CXC chemokine, $1 \mathrm{CX} 3 \mathrm{C}$, and 1 XC receptors have been identified (Rossi \& Zlotnik, 2000; Zlotnik \&Yoshie, 2000; Balabanian et al., 2005). Many chemokines, including CCL1, CCL2, CCL3, CCL4, CCL5, CCL10, CCL11, CCL13, CCL17, CCL18, CCL20, CCL22, CCL26, CCL27, CCL28, CX3CL1, CXCL9, CXCL10, CXCL12, have been presumed to be involving in AD phenotype (Homey et al., 2006; Toda et al., 2003; Hayashida et al., 2011; Piancatelli et al., 2008; Jahnz-Rozyk et al., 2005; T.F.Leung et al., 2003; Miyahara et al., 2011; Hon et al., 2004,2007; Kagami et al., 2003,2005; Yoshizawa et al., 2002; Park\&Youn, 2007; Kakinuma et al; 2003; Ezzat \&Shaheen, 2009; Echigo et al., 2004) (in table2). These researches indicated that the imbalance in serum concentration of Th-1- and Th-2-derived chemokines may be one of the factors involved in pathogenesis of AD and biomarkers of AD disease severity.

CXCL9, CXCL10, and CXCL11 are Th-1-derived chemokines, while CCL11, CCL17, CCL22, CCL27 are Th-2-derived chemokines, leading to preferential influx of T1/Th2 lymphocytes to the lesion of AD respectively (Narbutt et al., 2009). CCL28 is recently identified to be selectively expressed by keratinocytes and its functional ligands are CCR3 and CCR10. CCL28 is similar to CCL27 in human, they shares $40 \%$ amino acid identity(Hieshima et al., 2003). CCL26, CCL11 through CCR3 contribute to eosinophils recruitment to the lesion of $\mathrm{AD}$ (Homey et al., 2006). CX3CL1 originates from the endothelial cell and its receptor is CX3CR1, which can direct several kinds of immunological effective cells (such as T cell, NK cell and monocytes and DC) (Echigo et al., 2004).

Research by Narbutt J et al indicated that the serum level of CXCL9 and CXCL10 was decreased in childhood AD (Narbutt et al., 2009). While there were many study indicating that CCL11, CCL17, CCL22, CCL27 level in the serum were increased in AD patients and correlated with disease severity (T.F.Leung et al., 2003; Mostafa et al., 2008; Nagy et al., 2011; Song et al., 2006; Sohn et al., 2004; Kakinuma et al., 2002,2008; Jahnz-Rozyk et al., 2005; Hijnen et al., 2004; Kakinuma et al., 2001). Among the Th2 chemokines, serum CCL27 correlated most significantly with the severity of AD (Nakazato et al., 2008). The research by Miyahara et al showed that increased level of CCL17 in umbilical cord serum of neonates destined to develop AD in infancy (Miyahara et al., 2011).But another research indicated that the serum level of CCL17 and IL-18 were decreased, and CXCL12 and CCL27 increased in kids younger than 10 years old. In childhood AD of over 10 years old, serum concentration of CXCL12, CCL17, CCL22 was higher (Toda et al., 2003).There are many research results confirmed that the increased CCL28 level in the serum of AD patients and correlated positively to the severity scores (Jahnz-Rozyk et al., 2005; T.F. Leung et al., 2003; Ezzat \&Shaheen ,2009; Kagami et al., 2005; Ezzat et al., 2009), so CCL28 may be a useful parameter in the clinical diagnosis and prognosis after proper treatment. CCL26, as a chemokine attract eosinophils to the skin lesion is elevated in the serum and significantly correlated with the serum CCL17 and CCL22 levels, peripheral blood eosinophil numbers and SCORAD index (Kagami et al., 2003). 
Taken together, interleukins and chemokines are important markers in AD. But the normal levels in infancy and age-specific analysis in atopic dermatitis of these markers have not been well determined, this should be taken into account when interpreting the results, especially in infant AD.

\section{Tumor necrosis factor(TNF)}

B cell-activating factor (BAFF) is a member of tumour necrosis factor superfamily. BAFF plays an important role in the survival and maturation of B lymphocyte cells. The level of serum BAFF in childhood AD patients increased and significantly correlated with total serum IgE level and total eosinophil count in peripheral blood(Jee et al., 2010).While , in another research, serum BAFF level was not elevated in patients with AD (Matsushita et al., 2008).

\section{Neurotrophins and neuropeptides, Growth factors and hormones}

The Neurotrophins (NT) family including Nerve growth factor (NGF), Brain-derived neurotrophic factor (BDNF), NT- 3,4,5, 6 and NT- 7 (Leibrock et al., 1989; Kolbeck et al., 1994). The biologic effects of NT family are not merely restricted to the central nervous system but also relevant to the nerve cells present in other organs including the skin. More and more studies have demonstrated that NTs play an important role in the pathogenesis of AD. Association of BDNF gene polymorphisms and the increased serum levels in AD patients was conformed. The level of BDNF in the serum was correlated with intrinsic type of AD severity (Ma et al.,2010; Raap et al., 2006).While the level of NGF in serum has no significant correlation with total IgE, or severity of disease assessed by SCORAD (Schulte-Herbruggen et al., 2007). Although serum levels of vasoactive intestinal peptide (VIP) are found to be increased in patients with $\mathrm{AD}$, there was no correlation between serum VIP levels and disease severity, serum LDH levels, total serum IgE levels, and peripheral blood eosinophil counts in patients with AD (Umemoto er al., 2003). Also there was also no association between serum VIP concentration and itch intensity (C.H.Lee et al., 2006). A study showed TEWL, serum IgE and beta-endorphin were independent parameters for assessing itch intensity in AD (C.H.Lee et al., 2006).

Mast cell in the lesions is thought to play an important role in the pathogenesis of AD. Stem cell factor (SCF), and the interaction of SCF and its receptor, KIT (tyrosine kinase transmembrane receptor) are the key factors that induce mast cell growth, migration and differentiation. Serum levels of soluble SCF and soluble KIT were significantly elevated in AD patients, positively correlated with the disease severity, and decreased after effective treatment with topical corticosteroids (Kanbe et al., 2001).

Significantly higher expression of thymic stromal lymphopoietin (TSLP), an IL-7 - like cytokine, by lesional skin can induce DCs to express Th2 cell - polarizing signals in AD. DCs activated by TSLP can induce Th0 to differentiate into Th2 cells and play important roles in the maintenance and regulation of Th2 memory cells (Wang et al., 2006). While the serum TSLP level is inconsistent by different clinical study (E.B.Lee et al., 2010; Alysandratos et al., 2010; Nakamura et al., 2008).

The increasing level of serum antidiuretic hormone (ADH) in severe AD was confirmed, which was related with TEWL(Aoki, et al., 2005).

\subsubsection{Enzymes}

In the $\mathrm{AD}$ lesion, high lactate dehydrogenase(LDH) activity was found, especially in the epidermis. Also in the serum, the level of LDH and its isozyme (LDH4 and LDH5) is 
increased. After recovery of the patients, the serum LDH activity tended to decline. But there are no correlation between the LDH level and eosinocyte count in the peripheral blood or serum IgE level (Morishima et al., 2010).

Matrix metalloproteinases(MMPs) and their inhibitors, tissue inhibitors of metalloproteinases (TIMPs), are involved in inflammation mediated tissue destruction and remodeling. The maintenance of homeostasis of MMPs/TIMPs in the lesion is regulated by proinflammatory cytokines and growth factors (Woessner, 2001). In the study of Katoh $\mathrm{N}$ et al, they found that the level of TIMP-1 in the serum of AD patients was significantly increased, but reduced after treatments. The TIMP-1 level correlated with peripheral eosinophil counts, serum levels of $\mathrm{IgE}$ and $\mathrm{LDH}$, eruption score, and eruption area. Moreover, the patients with chronic eruptions (lichenification and prurigo) had significantly higher TIMP-1 levels, while those with acute lesions were not correlated with TIMP-1 level in the serum. The authors gave a hypothesis that serum TIMP-1 level may be a useful marker to estimate the long-term disease activity of AD (Katoh et al., 2002).

Human tissue kallikreins, or kallikrein-related peptidases (KLKs), are the largest family of trypsin- or chymotrypsin-like serine proteases (SPs). At least eight KLKs are expressed in normal skin, of which KLK8, KLK5, KLK7 have been reported to be the most important KLKs involved in maintenance of the homeostasis of normal epidermis by cleaving corneodesmosomes. Moreover, KLK5 and KLK14 activate protease-activated receptor (PAR)-2, which is a signaling receptor in epidermal inflammation and a regulator of epidermal barrier function (Meyer-Hoffert, 2009). In the lesion of AD, the level of KLKs were increased (Voegeli et al., 2009). In the serum of AD, KLK8 was reported significantly elevated, while KLK5 and KLK11 were significantly decreased (Komatsu et al., 2007). The different expression between lesion and serum may be due to the diversity of the origins of KLKs from many tissues and organs.

Neopterin is biosynthesized from guanosine triphosphate and produced preferentially by monocytes and macrophages. Increased neopterin concentrations in serum or urine are connected with diseases linked with cellular immune reaction. Recently, serum neopterin levels was reported to increase and to be considered as a diagnostic marker of $\mathrm{AD}$ (Ciprandi et al., 2011).

\subsubsection{Soluble immune receptors (SIRs)}

The serum levels of SIRs, such as sCD14, sCD23, sCD25 and sCD30 have been reported to be associated with AD (Ott et al., 2010; El Mongy et al., 2008; Di Lorenzo er al., 2003; Hon et al., 2005; Furue et al., 1999). CD30 released by CD30+ cells, a member of the TNF receptor superfamily, is a costimulatory molecule expressed on activated $\mathrm{T}$ and B cells. After cell activation, its extracellular domain generates soluble CD30 (sCD30) by enzymatic cleavage. Serum sCD30 is regarded as a indicator of Th2-type immune responses (El Mongy et al., 2008). Although there were several researches indicated that serum sCD30 levels were significantly higher and correlated positively with the severity of AD as assessed by SCORAD, age and duration of the disease (El Mongy et al., 2008; Di Lorenzo et al., 2003). Ott $\mathrm{H}$ et al indicated that the serum level of sCD23, sCD25 and sCD30 were highly aged dependent and can not be regarded as useful biomarkers for assessment of childhood AD (Ott et al., 2010).

\subsubsection{Others in serum}

Serum immunoglobulin free light chains (FLC) is classically associated with monoclonal gammopathies. An significantly increased level of FLC was observed in severe AD, while 
the association of FLC levels with age or total IgE levels was not confirmed (Kayserova et al., 2010).Vitamin D deficiency may be related to the severity of AD in the children patients. The level of serum in severe AD was significant lower than the mild AD (Peroni et al., 2010).

\subsubsection{Biomarkers in urine}

Leukotriene B4 (LTB4), LTC4, LTD4 and LTE4, the products of the oxidative metabolism of cell membrane arachidonic acid are secreted from eosinophils, mast cells and other inflammatory cells. As LTE4 is stable in urine, the urinal level of LTE4 may be a good marker for activation of mast cells and eosinophils in vivo. Urinary LTE4 increased in severe $\mathrm{AD}$ and correlated with severity of AD in children had been confirmed. Those having to sensitization to common allergens had higher LTE4 level than those without in the severe AD (Hon et al., 2004; Oymar \&Aksnes, 2005).

EDN/EPX, one of the major proinflammatory mediators released by activated eosinophils, can induce severe tissue damage and maintenance and exacerbation of AD. A positive correlation between the SCORAD and serum ECP and urine EPX levels has been reported in children and adult patients (Breuer et al., 2001; Pucci et al., 2005; Pucci et al., 2000; Goto et al., 2007), also correlated with visual analog scales (VAS) scores for itching(Goto et al., 2007). While urinary EDN concentrations did not correlate with the number of eosinophils in the peripheral blood (Goto et al., 2007).

Urinary nitrate level significantly increased in AD patients. The severity and extent of AD significantly correlated with urinary nitrate and malondialdehyde level, but it did not correlate with urinary 8-hydroxydeoxyguanosine (8-OHdG) level (Nakai et al., 2009).

The increased TEWL in AD is attributable partly to impaired barrier function of the skin. Remarkable loss of body fluid would induce a series of systemic regulatory reactions. The functional antidiuretic hormone (ADH)-aquaporin (AQP)-2 axis is a major regulatory system to keep water balance. Increased serum $\mathrm{ADH}$ was detected in severe $\mathrm{AD}$, a result possibly due to a dehydrated state caused by increased TEWL in these patients (Aoki, 2005). Recently, Urinary aquaporin-2 was found to be increased in infant AD patients, and positively correlate with skin dryness of infant $\mathrm{AD}$, but its concentrations did not correlate with the number of eosinophils in the peripheral blood and the total IgE level in serum and disease severity (Di et al., 2010).

Increased neopterin levels in serum or urine are connected with diseases related with cellular immune reaction (Murr et al., 2002).In the association study by Horak E et al between neopterin in cord blood and urine in early childhood and the development of atopic dermatitisAD, they showed that family history of atopic disease was associated with lower urinary neopterin levels at age of 6 years (Horak er al., 2006).

Prostaglandin D2 (PGD2), the major cyclooxygenase product of mast cells, is a good marker for mast cell activation. In the lung, PGD2 converts to 9a, 11b-prostaglandin F2 (9a,11bPGF2), which can be detected in the urine (O'Sullivan, 1999). The study of Oymar K and Aksnes L indicated that 9a, 11b-PGF2 level in the urine of severe childhood AD patients was increased and indicated that 9a, 11b-PGF2 may be a useful biomarker of mast cell activation in the urine (Oymar \&Aksnes, 2004).

\section{Conclusions}

$\mathrm{AD}$ is a complex cutaneous disorder characterized by local and/or systemic immune reactions, and skin barrier dysfunction. Its clinical manifestations are affected by many 
factors, such as gene, environment, race, age etc. Further studies should be performed to findings of definitive biomarkers to assess the disease severity and evaluation of treatment effects. But the normal levels in infancy and age-specific analysis in AD of these markers have not been well determined, this should be taken into account when interpreting the results, especially in infant $\mathrm{AD}$.

\section{Abbreviations}

Atopic dermatitis (AD);

Hanifin and Rajka diagnostic criteria (H-R criteria);

International Study of Asthma and Allergies in Childhood (ISAAC);

Quality of life (QoL);

Scoring Atopic Dermatitis index (SCORAD);

Dermatitis Area and Severity Index score (ADASIS);

Eczema Area and Severity Index (EASI);

Psoriasis area and severity index (PASI);

Nottingham Eczema Severity Score (NESS);

Children's Dermatology Life Quality Index (CDLQI);

Objective severity assessment of atopic dermatitis (OSAAD system);

Stratum corneum hydration $(\mathrm{SCH})$;

Trans-epidermal water loss (TEWL);

Body surface area (BSA);

Stratum corneum (SC);

Natural moisturizing factors (NMF);

Pyrrolidone carboxylic acid (PCA);

Urocanic acid (UCA);

Atopy patch test (APT);

Skin prick test (SPT);

Eosinophil cationic protein (ECP);

Eosinophil derived neurotoxin/eosinophil protein X (EDN/EPX);

T-regulatory (Treg);

Interleukin (IL);

CCL2/MCP-1, monocyte chemotactic protein 1;

CCL11 / eotaxin (EOX);

CCL17 / TARC, thymus and activation-regulated chemokine;

CCL22 /MDC, macrophage-derived chemokine;

CCL26 / eotaxin-3;

CCL27/CTACK, cutaneous T cell-attracting chemokine;

CCL28/ MEC, Mucosa-associated epithelial chemokine;

CXCL10 / IP-10, IFN-induced protein of $10 \mathrm{kd}$;

CX3CL1 / fractalkine;

sE-selectin, serum soluble E-selectin ;

sIL-2R, soluble interleukin-2 receptor .

Tumor necrosis factor (TNF);

B cell-activating factor (BAFF);

Neurotrophins (NT);

Nerve growth factor (NGF); 
Brain-derived neurotrophic factor (BDNF);

Vasoactive intestinal peptide (VIP);

Stem cell factor (SCF);

Tyrosine kinase transmembrane receptor (KIT);

Thymic stromal lymphopoietin (TSLP);

Dendric cell (DC);

Antidiuretic hormone (ADH);

Lactate dehydrogenase(LDH);

Matrix metalloproteinases(MMPs);

Tissue inhibitors of metalloproteinases (TIMPs);

Kallikreins (KLKs);

Soluble immune receptors (SIRs;)

Free light chains (FLC);

Leukotriene(LT);

Visual analog scales (VAS);

8-hydroxydeoxyguanosine (8-OHdG);

Aquaporin (AQP);

Prostaglandin D (PGD)

\section{References}

Agrawal, R.;Wisniewski, J.A. \&Woodfolk, J.A. (2011). Curr Probl Dermatol. The role of regulatory T cells in atopic dermatitis, Vol.41, pp. 112-124,ISSN 1662-2944

Akdis, C.A.;Blesken, T.;Akdis, M. (1998). J Clin Invest. Role of interleukin 10 in specific immunotherapy, Vol.102, No.1, pp. 98-106,ISSN 0021-9738

Akdis, C.A.;Akdis, M.;Bieber, T. (2006). Allergy. Diagnosis and treatment of atopic dermatitis in children and adults: European Academy of Allergology and Clinical Immunology/American Academy of Allergy, Asthma and Immunology/ PRACTALL Consensus Report, Vol.61, No.8, pp. 969-987,ISSN 0105-4538

Akdis, M.;Verhagen, J.;Taylor, A. (2004). J Exp Med. Immune responses in healthy and allergic individuals are characterized by a fine balance between allergen-specific $\mathrm{T}$ regulatory 1 and T helper 2 cells, Vol.199, No.11, pp. 1567-1575,ISSN 0022-1007

Altrichter, S.;Kriehuber, E.;Moser, J. (2008). J Invest Dermatol. Serum IgE autoantibodies target keratinocytes in patients with atopic dermatitis, Vol.128, No.9, pp. 2232-2239, ISSN 1523-1747

Alysandratos, K.D.;Angelidou, A.;Vasiadi, M. (2010). Ann Allergy Asthma Immunol. Increased affected skin gene expression and serum levels of thymic stromal lymphopoietin in atopic dermatitis, Vol.105, No.5, pp. 403-404,ISSN 1534-4436

Angelova-Fischer, I.;Bauer, A.;Hipler, U.C. (2005). Br J Dermatol. The objective severity assessment of atopic dermatitis (OSAAD) score: validity, reliability and sensitivity in adult patients with atopic dermatitis, Vol.153, No.4, pp. 767-773, ISSN 0007-0963

Aoki, T. (2005). Br J Dermatol. Serum antidiuretic hormone is elevated in relation to the increase in average total body transepidermal water loss in severe atopic dermatitis, Vol.153, No.2, pp. 359-363, ISSN 0007-0963

Aral, M.;Arican, O.;Gul, M. (2006). Mediators Inflamm. The relationship between serum levels of total IgE, IL-18, IL-12, IFN-gamma and disease severity in children with atopic dermatitis, Vol.2006, No.4, pp. 73098, ISSN 0962-9351 
Asher, M.I.;Keil, U.;Anderson, H.R. (1995). Eur Respir J. International Study of Asthma and Allergies in Childhood (ISAAC): rationale and methods, Vol.8, No.3, pp. 483-491, ISSN 0903-1936

Badertscher, K.;Bronnimann, M.;Karlen, S. (2005). Arch Dermatol Res. Mast cell chymase is increased in chronic atopic dermatitis but not in psoriasis, Vol.296, No.10, pp. 503506, ISSN 0340-3696

Bahmer, F.A. (1992). Acta Derm Venereol Suppl (Stockh). ADASI score: atopic dermatitis area and severity index, Vol.176, pp. 32-33, ISSN 0365-8341

Balabanian, K.;Lagane, B.;Infantino, S. (2005). J Biol Chem. The chemokine SDF-1/CXCL12 binds to and signals through the orphan receptor RDC1 in T lymphocytes, Vol.280, No.42, pp. 35760-35766, ISSN 0021-9258

Belloni Fortina, A.;Tonin, E.;Pigozzi, B. (2006). Int J Immunopathol Pharmacol. IL-16 serum level in children with atopic dermatitis, Vol.19, No.4, pp. 841-845, ISSN 0394-6320

Ben-Gashir, M.A.; Seed, P.T. \& Hay, R.J. (2004). Br J Dermatol. Quality of life and disease severity are correlated in children with atopic dermatitis, Vol.150, No.2, pp. 284290, ISSN 0007-0963

Boguniewicz, M.; Schmid-Grendelmeier, P. \& Leung, D.Y. (2006). J Allergy Clin Immunol. Atopic dermatitis, Vol.118, No.1, pp. 40-43, ISSN 0091-6749

Bradley, M.; Kockum, I.; Soderhall, C. (2000). Acta Derm Venereol. Characterization by phenotype of families with atopic dermatitis, Vol.80, No.2, pp. 106-110, ISSN 00015555

Brenninkmeijer, E.E.; Schram, M.E.; Leeflang, M.M. (2008). Br J Dermatol. Diagnostic criteria for atopic dermatitis: a systematic review, Vol.158, No.4, pp. 754-765, ISSN 00070963

Breuer, K.;Kapp, A. \&Werfel, T. (2001). Allergy. Urine eosinophil protein X (EPX) is an in vitro parameter of inflammation in atopic dermatitis of the adult age, Vol.56, No.8, pp. 780-784, ISSN 0105-4538

Caproni, M.; Antiga, E.; Torchia, D. (2007). Allergy Asthma Proc. FoxP3-expressing T regulatory cells in atopic dermatitis lesions, Vol.28, No.5, pp. 525-528, ISSN 10885412

Charman, C. \& Williams, H. (2000). Arch Dermatol. Outcome measures of disease severity in atopic eczema, Vol.136, No.6, pp. 763-769, ISSN 0003-987X

Choi, S.J.; Song, M.G.; Sung, W.T. (2003). J Korean Med Sci. Comparison of transepidermal water loss, capacitance and $\mathrm{pH}$ values in the skin between intrinsic and extrinsic atopic dermatitis patients, Vol.18, No.1, pp. 93-96, ISSN 1011-8934

Ciprandi, G.; De Amici, M.; Berardi, L. (2011). Clin Exp Dermatol. Serum neopterin levels in spontaneous urticaria and atopic dermatitis, Vol.36, No.1, pp. 85-87, ISSN 13652230

Consensus Report of the European Task Force on Atopic Dermatitis (1993). Dermatology. Severity scoring of atopic dermatitis: the SCORAD index., Vol.186, No.1, pp. 2331,ISSN 1018-8665

Damps-Konstanska, I.; Gruchala-Niedoszytko, M.; Wilkowska, A. (2005). Pol Merkur Lekarski. [Serum eosinophil cationic protein (ECP) in patients with perennial rhinitis and atopic dermatitis, allergic to house dust mites], Vol.19, No.114, pp. 765768, ISSN 1426-9686 
de Boissieu, D. \& Dupont, C. (2003). Eur Ann Allergy Clin Immunol. [Patch tests in the diagnosis of food allergies in the nursing infant], Vol.35, No.5, pp. 150-152, ISSN 1764-1489

Di Lorenzo, G.; Gangemi, S.; Merendino, R.A. (2003). Mediators Inflamm. Serum levels of soluble CD30 in adult patients affected by atopic dermatitis and its relation to age, duration of disease and Scoring Atopic Dermatitis index, Vol.12, No.2, pp. 123-125, ISSN 0962-9351

Di, Z.H.; Lv, Y.N.; Zhang, L. (2010). Br J Dermatol. Urinary aquaporin-2 is elevated in infant atopic dermatitis, Vol.163, No.5, pp. 1132-1134, ISSN 1365-2133

Echigo, T.; Hasegawa, M.; Shimada, Y. (2004). J Allergy Clin Immunol. Expression of fractalkine and its receptor, CX3CR1, in atopic dermatitis: possible contribution to skin inflammation, Vol.113, No.5, pp. 940-948, ISSN 0091-6749

El Mongy, S.; Metwaly, S.S.; Arafat, M.S. (2008). Egypt J Immunol. Serum levels of soluble CD30 in patients with atopic dermatitis: correlations with age, disease duration and severity, Vol.15, No.1, pp. 123-129, ISSN 1110-4902

Elkeeb, R.; Hui, X.; Chan, H. (2010). Skin Res Technol. Correlation of transepidermal water loss with skin barrier properties in vitro: comparison of three evaporimeters, Vol.16, No.1, pp. 9-15, ISSN 1600-0846

Emerson, R.M.; Charman, C.R. \& Williams, H.C. (2000). Br J Dermatol. The Nottingham Eczema Severity Score: preliminary refinement of the Rajka and Langeland grading, Vol.142, No.2, pp. 288-297, ISSN 0007-0963

Ezzat, M.; Hasan, Z. \& Shaheen, K. (2011). J Eur Acad Dermatol Venereol. Serum measurement of interleukin-31 (IL-31) in paediatric atopic dermatitis: elevated levels correlate with severity scoring, Vol.25, No.3, pp. 334-339, ISSN 1468-3083

Ezzat, M.H.; Sallam, M.A. \& Shaheen, K.Y. (2009). Int J Dermatol. Serum mucosa-associated epithelial chemokine (MEC/CCL28) in atopic dermatitis: a specific marker for severity, Vol.48, No.8, pp. 822-829, ISSN 1365-4632

Ezzat, M.H. \& Shaheen, K.Y. (2009). Indian J Dermatol. Serum mucosa-associated epithelial chemokine in atopic dermatitis: a specific marker for severity, Vol.54, No.3, pp. 229236, ISSN 1998-3611

Firooz, A.; Gorouhi, F.; Davari, P. (2007). Clin Exp Dermatol. Comparison of hydration, sebum and $\mathrm{pH}$ values in clinically normal skin of patients with atopic dermatitis and healthy controls, Vol.32, No.3, pp. 321-322, ISSN 0307-6938

Furue, M.; Koga, T. \& Yamashita, N. (1999). Br J Dermatol. Soluble E-selectin and eosinophil cationic protein are distinct serum markers that differentially represent clinical features of atopic dermatitis, Vol.140, No.1, pp. 67-72, ISSN 0007-0963

Gerdes, S.; Kurrat, W. \& Mrowietz, U. (2009). Br J Dermatol. Serum mast cell tryptase is not a useful marker for disease severity in psoriasis or atopic dermatitis, Vol.160, No.4, pp. 736-740, ISSN 1365-2133

Goto, T.; Morioka, J.; Inamura, H. (2007). Allergol Int. Urinary eosinophil-derived neurotoxin concentrations in patients with atopic dermatitis: a useful clinical marker for disease activity, Vol.56, No.4, pp. 433-438, ISSN 1323-8930

Gupta, J.; Grube, E.; Ericksen, M.B. (2008). J Allergy Clin Immunol. Intrinsically defective skin barrier function in children with atopic dermatitis correlates with disease severity, Vol.121, No.3, pp. 725-730 e722, ISSN 1097-6825 
Hanifin, J.M.; Thurston, M.; Omoto, M. (2001). Exp Dermatol. The eczema area and severity index (EASI): assessment of reliability in atopic dermatitis. EASI Evaluator Group, Vol.10, No.1, pp. 11-18, ISSN 0906-6705

Hayashida, S.; Uchi, H.; Moroi, Y. (2011). J Dermatol Sci. Decrease in circulating Th17 cells correlates with increased levels of CCL17, IgE and eosinophils in atopic dermatitis, Vol.61, No.3, pp. 180-186, ISSN 1873-569X

Hayashida, S.; Uchi, H.; Takeuchi, S. (2011). J Dermatol Sci. Significant correlation of serum IL-22 levels with CCL17 levels in atopic dermatitis, Vol.61, No.1, pp. 78-79, ISSN 1873-569X

Hieshima, K.; Ohtani, H.; Shibano, M. (2003). J Immunol. CCL28 has dual roles in mucosal immunity as a chemokine with broad-spectrum antimicrobial activity, Vol.170, No.3, pp. 1452-1461, ISSN 0022-1767

Hijnen, D.; De Bruin-Weller, M.; Oosting, B. (2004). J Allergy Clin Immunol. Serum thymus and activation-regulated chemokine (TARC) and cutaneous $\mathrm{T}$ cell- attracting chemokine (CTACK) levels in allergic diseases: TARC and CTACK are diseasespecific markers for atopic dermatitis, Vol.113, No.2, pp. 334-340, ISSN 0091-6749

Homey, B.; Steinhoff, M.; Ruzicka, T. (2006). J Allergy Clin Immunol. Cytokines and chemokines orchestrate atopic skin inflammation, Vol.118, No.1, pp. 178-189, ISSN 0091-6749

Hon, K.L.; Leung, T.F.; Ma, K.C. (2004). Clin Exp Dermatol. Serum levels of cutaneous T-cell attracting chemokine (CTACK) as a laboratory marker of the severity of atopic dermatitis in children, Vol.29, No.3, pp. 293-296, ISSN 0307-6938

Hon, K.L.; Leung, T.F.; Ma, K.C. (2004). Clin Exp Dermatol. Urinary leukotriene E4 correlates with severity of atopic dermatitis in children, Vol.29, No.3, pp. 277-281, ISSN 0307-6938

Hon, K.L.; Leung, T.F.; Ma, K.C. (2004). Pediatr Dermatol. Serum concentration of IL-18 correlates with disease extent in young children with atopic dermatitis, Vol.21, No.6, pp. 619-622, ISSN 0736-8046

Hon, K.L.; Leung, T.F.; Ma, K.C. (2005). J Dermatolog Treat. Brief case series: montelukast, at doses recommended for asthma treatment, reduces disease severity and increases soluble CD14 in children with atopic dermatitis, Vol.16, No.1, pp. 15-18, ISSN 09546634

Hon, K.L.; Kam, W.Y.; Lam, M.C. (2006). Qual Life Res. CDLQI, SCORAD and NESS: are they correlated?, Vol.15, No.10, pp. 1551-1558, ISSN 0962-9343

Hon, K.L.; Lam, M.C.; Leung, T.F. (2007). Int J Dermatol. Are age-specific high serum IgE levels associated with worse symptomatology in children with atopic dermatitis?, Vol.46, No.12, pp. 1258-1262, ISSN 0011-9059

Hon, K.L.;Wong, K.Y.;Leung, T.F. (2008). Am J Clin Dermatol. Comparison of skin hydration evaluation sites and correlations among skin hydration, transepidermal water loss, SCORAD index, Nottingham Eczema Severity Score, and quality of life in patients with atopic dermatitis, Vol.9, No.1, pp. 45-50, ISSN 1175-0561

Horak, E.; Murr, C.; Streif, W. (2006). Pediatr Allergy Immunol. Association between neopterin in cord blood, urinary neopterin in early childhood and the development of atopic dermatitis, asthma and hay fever, Vol.17, No.1, pp. 11-16, ISSN 0905-6157 
Howell, M.D.; Kim, B.E.; Gao, P. (2009). J Allergy Clin Immunol. Cytokine modulation of atopic dermatitis filaggrin skin expression, Vol.124, No.3 Suppl 2, pp. R7-R12, ISSN 1097-6825

Isolauri, E. \& Turjanmaa, K. (1996). J Allergy Clin Immunol. Combined skin prick and patch testing enhances identification of food allergy in infants with atopic dermatitis, Vol.97, No.1 Pt 1, pp. 9-15, ISSN 0091-6749

Jahnz-Rozyk, K.; Targowski, T.; Paluchowska, E. (2005). Allergy. Serum thymus and activation-regulated chemokine, macrophage-derived chemokine and eotaxin as markers of severity of atopic dermatitis, Vol.60, No.5, pp. 685-688, ISSN 0105-4538

Jee, H.M.; Kim, K.W.; Hong, J.Y. (2010). Clin Exp Dermatol. Increased serum B cellactivating factor level in children with atopic dermatitis, Vol.35, No.6, pp. 593-598, ISSN 1365-2230

Jenerowicz, D.; Czarnecka-Operacz, M. \& Silny, W. (2006). Acta Dermatovenerol Croat. Selected eosinophil proteins as markers of inflammation in atopic dermatitis patients, Vol.14, No.2, pp. 73-80, ISSN 1330-027X

Kagami, S.; Kakinuma, T.; Saeki, H. (2003). Clin Exp Immunol. Significant elevation of serum levels of eotaxin-3/CCL26, but not of eotaxin-2/CCL24, in patients with atopic dermatitis: serum eotaxin-3/CCL26 levels reflect the disease activity of atopic dermatitis, Vol.134, No.2, pp. 309-313, ISSN 0009-9104

Kagami, S.; Kakinuma, T.; Saeki, H. (2005). J Invest Dermatol. Increased serum CCL28 levels in patients with atopic dermatitis, psoriasis vulgaris and bullous pemphigoid, Vol.124, No.5, pp. 1088-1090, ISSN 0022-202X

Kakinuma, T.; Nakamura, K.; Wakugawa, M. (2001). J Allergy Clin Immunol. Thymus and activation-regulated chemokine in atopic dermatitis: Serum thymus and activationregulated chemokine level is closely related with disease activity, Vol.107, No.3, pp. 535-541, ISSN 0091-6749

Kakinuma, T.; Nakamura, K.; Wakugawa, M. (2002). Clin Exp Immunol. Serum macrophage-derived chemokine (MDC) levels are closely related with the disease activity of atopic dermatitis, Vol.127, No.2, pp. 270-273, ISSN 0009-9104

Kakinuma, T.; Saeki, H.;Tsunemi, Y. (2003). J Allergy Clin Immunol. Increased serum cutaneous $\mathrm{T}$ cell-attracting chemokine (CCL27) levels in patients with atopic dermatitis and psoriasis vulgaris, Vol.111, No.3, pp. 592-597, ISSN 0091-6749

Kanbe, T.; Soma, Y.; Kawa, Y. (2001). Br J Dermatol. Serum levels of soluble stem cell factor and soluble KIT are elevated in patients with atopic dermatitis and correlate with the disease severity, Vol.144, No.6, pp. 1148-1153, ISSN 0007-0963

Katoh, N.; Hirano, S.; Suehiro, M. (2002). Clin Exp Immunol. Increased levels of serum tissue inhibitor of metalloproteinase- 1 but not metalloproteinase- 3 in atopic dermatitis, Vol.127, No.2, pp. 283-288, ISSN 0009-9104

Kayserova, J.; Capkova, S.; Skalicka, A. (2010). Scand J Immunol. Serum immunoglobulin free light chains in severe forms of atopic dermatitis, Vol.71, No.4, pp. 312-316, ISSN 1365-3083

Kezic, S.; O'Regan, G.M.; Yau, N. (2011). Allergy. Levels of filaggrin degradation products are influenced by both filaggrin genotype and atopic dermatitis severity, ISSN 1398-9995

Kolbeck, R.; Jungbluth, S. \& Barde, Y.A. (1994). Eur J Biochem. Characterisation of neurotrophin dimers and monomers, Vol.225, No.3, pp. 995-1003, ISSN 0014-2956 
Komatsu, N.; Saijoh, K.; Kuk, C. (2007). Exp Dermatol. Human tissue kallikrein expression in the stratum corneum and serum of atopic dermatitis patients, Vol.16, No.6, pp. 513-519, ISSN 0906-6705

Kunz, B.; Oranje, A.P.; Labreze, L. (1997). Dermatology. Clinical validation and guidelines for the SCORAD index: consensus report of the European Task Force on Atopic Dermatitis, Vol.195, No.1, pp. 10-19, ISSN 1018-8665

Landmann, L. (1988). Anat Embryol (Berl). The epidermal permeability barrier, Vol.178, No.1, pp. 1-13, ISSN 0340-2061

Lee, C.H.;Chuang, H.Y.;Shih, C.C. (2006). Br J Dermatol. Transepidermal water loss, serum IgE and beta-endorphin as important and independent biological markers for development of itch intensity in atopic dermatitis, Vol.154, No.6, pp. 1100-1107, ISSN 0007-0963

Lee, E.B.; Kim, K.W.; Hong, J.Y. (2010). Pediatr Allergy Immunol. Increased serum thymic stromal lymphopoietin in children with atopic dermatitis, Vol.21, No.2 Pt 2, pp. e457-460, ISSN 1399-3038

Lee, K.Y.; Cho, K.J.; Kim, Y.T. (2009). Ann Allergy Asthma Immunol. Serum eosinophilderived neurotoxin in childhood atopic dermatitis: a useful marker of disease activity?, Vol.102, No.6, pp. 532-534, ISSN 1081-1206

Leibrock, J.; Lottspeich, F.; Hohn, A. (1989). Nature. Molecular cloning and expression of brain-derived neurotrophic factor, Vol.341, No.6238, pp. 149-152, ISSN 0028-0836

Leung, D.Y.; Boguniewicz, M.; Howell, M.D. (2004). J Clin Invest. New insights into atopic dermatitis, Vol.113, No.5, pp. 651-657, ISSN 0021-9738

Leung, T.F.; Ma, K.C.; Hon, K.L. (2003). Pediatr Allergy Immunol. Serum concentration of macrophage-derived chemokine may be a useful inflammatory marker for assessing severity of atopic dermatitis in infants and young children, Vol.14, No.4, pp. 296-301, ISSN 0905-6157

Levy, R.M.; Gelfand, J.M. \& Yan, A.C. (2003). Clin Dermatol. The epidemiology of atopic dermatitis, Vol.21, No.2, pp. 109-115, ISSN 0738-081X

Lipozencic, J. \& Wolf, R. (2007). Dermatol Clin. Atopic dermatitis: an update and review of the literature, Vol.25, No.4, pp. 605-612, x, ISSN 0733-8635

Lipozencic, J. \& Wolf, R. (2010). Clin Dermatol. The diagnostic value of atopy patch testing and prick testing in atopic dermatitis: facts and controversies, Vol.28, No.1, pp. 3844, ISSN 1879-1131

Ma, L.; Gao, X.H.; Zhao, L.P. (2009). J Eur Acad Dermatol Venereol. Brain-derived neurotrophic factor gene polymorphisms and serum levels in Chinese atopic dermatitis patients, Vol.23, No.11, pp. 1277-1281, ISSN 1468-3083

Ma, L.; Zhang, L.; Di, Z.H. (2010). Br J Dermatol. Association analysis of filaggrin gene mutations and atopic dermatitis in Northern China, Vol.162, No.1, pp. 225-227, ISSN 1365-2133

Man, M.Q.; Xin, S.J.; Song, S.P. (2009). Skin Pharmacol Physiol. Variation of skin surface pH, sebum content and stratum corneum hydration with age and gender in a large Chinese population, Vol.22, No.4, pp. 190-199, ISSN 1660-5535

Marenholz, I.; Nickel, R.; Ruschendorf, F. (2006). J Allergy Clin Immunol. Filaggrin loss-offunction mutations predispose to phenotypes involved in the atopic march, Vol.118, No.4, pp. 866-871, ISSN 0091-6749 
Masuda, K.; Katoh, N.; Okuda, F. (2003). Acta Derm Venereol. Increased levels of serum interleukin-16 in adult type atopic dermatitis, Vol.83, No.4, pp. 249-253, ISSN 00015555

Mathy, N.L.; Scheuer, W.; Lanzendorfer, M. (2000). Immunology. Interleukin-16 stimulates the expression and production of pro-inflammatory cytokines by human monocytes, Vol.100, No.1, pp. 63-69, ISSN 0019-2805

Matsushita, T.; Fujimoto, M.; Echigo, T. (2008). Exp Dermatol. Elevated serum levels of APRIL, but not BAFF, in patients with atopic dermatitis, Vol.17, No.3, pp. 197-202, ISSN 1600-0625

Mevorah, B.; Frenk, E.; Wietlisbach, V. (1988). Dermatologica. Minor clinical features of atopic dermatitis. Evaluation of their diagnostic significance, Vol.177, No.6, pp. 360364, ISSN 0011-9075

Meyer-Hoffert, U. (2009). Arch Immunol Ther Exp (Warsz). Reddish, scaly, and itchy: how proteases and their inhibitors contribute to inflammatory skin diseases, Vol.57, No.5, pp. 345-354, ISSN 1661-4917

Miyahara, H.; Okazaki, N.; Nagakura, T. (2011). Clin Exp Allergy. Elevated umbilical cord serum TARC/CCL17 levels predict the development of atopic dermatitis in infancy, Vol.41, No.2, pp. 186-191, ISSN 1365-2222

Morishima, Y.; Kawashima, H.; Takekuma, K. (2010). Pediatr Int. Changes in serum lactate dehydrogenase activity in children with atopic dermatitis, Vol.52, No.2, pp. 171174, ISSN 1442-200X

Mostafa, G.A.; Tomoum, H.Y.; Salem, S.A. (2008). Pediatr Allergy Immunol. Serum concentrations of CCR4 ligands in relation to clinical severity of atopic dermatitis in Egyptian children, Vol.19, No.8, pp. 756-762, ISSN 1399-3038

Murr, C.; Widner, B.; Wirleitner, B. (2002). Curr Drug Metab. Neopterin as a marker for immune system activation, Vol.3, No.2, pp. 175-187, ISSN 1389-2002

Nagy, G.; Gaspar, K.; Irinyi, B. (2011). Int Arch Allergy Immunol. Association between Serum IL-16 Levels and the Degree of Sensitization in Patients with Atopic Dermatitis, Vol.156, No.1, pp. 69-74, ISSN 1423-0097

Nakai, K.; Yoneda, K.; Maeda, R. (2009). J Eur Acad Dermatol Venereol. Urinary biomarker of oxidative stress in patients with psoriasis vulgaris and atopic dermatitis, Vol.23, No.12, pp. 1405-1408, ISSN 1468-3083

Nakamura, K.; Tsuchida, T.; Tsunemi, Y. (2008). J Dermatol. Serum thymic stromal lymphopoietin levels are not elevated in patients with atopic dermatitis, Vol.35, No.8, pp. 546-547, ISSN 0385-2407

Nakazato, J.; Kishida, M.; Kuroiwa, R. (2008). Pediatr Allergy Immunol. Serum levels of Th2 chemokines, CCL17, CCL22, and CCL27, were the important markers of severity in infantile atopic dermatitis, Vol.19, No.7, pp. 605-613, ISSN 1399-3038

Narbutt, J.; Lesiak, A.; Sysa-Jedrzeiowska, A. (2009). Mediators Inflamm. The imbalance in serum concentration of Th-1- and Th-2-derived chemokines as one of the factors involved in pathogenesis of atopic dermatitis, Vol.2009, pp. 269541, ISSN 1466-1861

Niggemann, B.; Reibel, S. \& Wahn, U. (2000). Allergy. The atopy patch test (APT)-- a useful tool for the diagnosis of food allergy in children with atopic dermatitis, Vol.55, No.3, pp. 281-285, ISSN 0105-4538 
Niggemann, B.; Rolinck-Werninghaus, C.; Mehl, A. (2005). Allergy. Controlled oral food challenges in children--when indicated, when superfluous?, Vol.60, No.7, pp. 865870, ISSN 0105-4538

Novak, N. \& Bieber, T. (2003). J Allergy Clin Immunol. Allergic and nonallergic forms of atopic diseases, Vol.112, No.2, pp. 252-262, ISSN 0091-6749

O'Regan, G.M.; Sandilands, A.; McLean, W.H. (2009). J Allergy Clin Immunol. Filaggrin in atopic dermatitis, Vol.124, No.3 Suppl 2, pp. R2-6, ISSN 1097-6825

O'Sullivan, S. (1999). Acta Physiol Scand Suppl. On the role of PGD2 metabolites as markers of mast cell activation in asthma, Vol.644, pp. 1-74, ISSN 0302-2994

Osterballe, M.; Andersen, K.E. \& Bindslev-Jensen, C. (2004). J Am Acad Dermatol. The diagnostic accuracy of the atopy patch test in diagnosing hypersensitivity to cow's milk and hen's egg in unselected children with and without atopic dermatitis, Vol.51, No.4, pp. 556-562, ISSN 1097-6787

Ott, H.; Stanzel, S.; Ocklenburg, C. (2009). Acta Derm Venereol. Total serum IgE as a parameter to differentiate between intrinsic and extrinsic atopic dermatitis in children, Vol.89, No.3, pp. 257-261, ISSN 0001-5555

Ott, H.; Wilke, J.; Baron, J.M. (2010). J Eur Acad Dermatol Venereol. Soluble immune receptor serum levels are associated with age, but not with clinical phenotype or disease severity in childhood atopic dermatitis, Vol.24, No.4, pp. 395-402, ISSN 1468-3083

Oymar, K. \& Aksnes, L. (2004). Acta Derm Venereol. Urinary 9alpha,11beta-prostaglandin $\mathrm{F}(2)$ in children with atopic eczema/dermatitis syndrome: an indicator of mast cell activation?, Vol.84, No.5, pp. 359-362, ISSN 0001-5555

Oymar, K. \& Aksnes, L. (2005). Allergy. Increased levels of urinary leukotriene E4 in children with severe atopic eczema/dermatitis syndrome, Vol.60, No.1, pp. 86-89, ISSN 0105-4538

Palmer, C.N.; Irvine, A.D.; Terron-Kwiatkowski, A. (2006). Nat Genet. Common loss-offunction variants of the epidermal barrier protein filaggrin are a major predisposing factor for atopic dermatitis, Vol.38, No.4, pp. 441-446, ISSN 1061-4036

Park do, S. \& Youn, Y.H. (2007). Korean J Lab Med. [Clinical significance of serum interleukin-18 concentration in the patients with atopic dermatitis], Vol.27, No.2, pp. 128-132, ISSN 1598-6535

Peroni, D.G.; Piacentini, G.L.; Cametti, E. (2010). Br J Dermatol. Correlation between serum $25(\mathrm{OH})$-vitamin D levels and severity of atopic dermatitis in children, ISSN 13652133

Piancatelli, D.; Bellotta, L.; Del Beato, T. (2008). Int J Immunopathol Pharmacol. Total IL-12 levels are increased in paediatric atopic dermatitis: correlations with age and disease severity, Vol.21, No.2, pp. 359-365, ISSN 0394-6320

Pucci, N.; Lombardi, E.; Novembre, E. (2000). J Allergy Clin Immunol. Urinary eosinophil protein $\mathrm{X}$ and serum eosinophil cationic protein in infants and young children with atopic dermatitis: correlation with disease activity, Vol.105, No.2 Pt 1, pp. 353-357, ISSN 0091-6749

Pucci, N.; Novembre, E.; Cammarata, M.G. (2005). Allergy. Scoring atopic dermatitis in infants and young children: distinctive features of the SCORAD index, Vol.60, No.1, pp. 113-116, ISSN 0105-4538 
Raap, U.; Werfel, T.; Goltz, C. (2006). Allergy. Circulating levels of brain-derived neurotrophic factor correlate with disease severity in the intrinsic type of atopic dermatitis, Vol.61, No.12, pp. 1416-1418, ISSN 0105-4538

Raap, U.; Wichmann, K.; Bruder, M. (2008). J Allergy Clin Immunol. Correlation of IL-31 serum levels with severity of atopic dermatitis, Vol.122, No.2, pp. 421-423, ISSN 1097-6825

Ring, J.; Darsow, U.; Gfesser, M. (1997). Int Arch Allergy Immunol. The 'atopy patch test' in evaluating the role of aeroallergens in atopic eczema, Vol.113, No.1-3, pp. 379-383, ISSN 1018-2438

Robinson, M.; Visscher, M.; Laruffa, A. (2010). J Cosmet Sci. Natural moisturizing factors (NMF) in the stratum corneum (SC). I. Effects of lipid extraction and soaking, Vol.61, No.1, pp. 13-22, ISSN 1525-7886

Robinson, M.; Visscher, M.; Laruffa, A. (2010). J Cosmet Sci. Natural moisturizing factors (NMF) in the stratum corneum (SC). II. Regeneration of NMF over time after soaking, Vol.61, No.1, pp. 23-29, ISSN 1525-7886

Roehr, C.C.; Reibel, S.; Ziegert, M. (2001). J Allergy Clin Immunol. Atopy patch tests, together with determination of specific IgE levels, reduce the need for oral food challenges in children with atopic dermatitis, Vol.107, No.3, pp. 548-553, ISSN 00916749

Roguedas, A.M.; Machet, L.; Fontes, V. (2004). Ann Dermatol Venereol. [Atopic dermatitis: which are the diagnostic criteria used in medical literature?], Vol.131, No.2, pp. 161164, ISSN 0151-9638

Rossi, D. \& Zlotnik, A. (2000). Annu Rev Immunol. The biology of chemokines and their receptors, Vol.18, pp. 217-242, ISSN 0732-0582

Rullo, V.E.; Segato, A.; Kirsh, A. (2008). Allergol Immunopathol (Madr). Severity scoring of atopic dermatitis: a comparison of two scoring systems, Vol.36, No.4, pp. 205-211, ISSN 0301-0546

Saarinen, K.M.; Suomalainen, H. \& Savilahti, E. (2001). Clin Exp Allergy. Diagnostic value of skin-prick and patch tests and serum eosinophil cationic protein and cow's milkspecific IgE in infants with cow's milk allergy, Vol.31, No.3, pp. 423-429, ISSN 09547894

Sampson, H.A. (2001). J Allergy Clin Immunol. Utility of food-specific IgE concentrations in predicting symptomatic food allergy, Vol.107, No.5, pp. 891-896, ISSN 0091-6749

Sampson, H.A. (2003). Clin Dermatol. The evaluation and management of food allergy in atopic dermatitis, Vol.21, No.3, pp. 183-192, ISSN 0738-081X

Schulte-Herbruggen, O.; Folster-Holst, R.; von Elstermann, M. (2007). Int Arch Allergy Immunol. Clinical relevance of nerve growth factor serum levels in patients with atopic dermatitis and psoriasis, Vol.144, No.3, pp. 211-216, ISSN 1423-0097

Selnes, A. \& Dotterud, L.K. (2005). J Eur Acad Dermatol Venereol. No association between serum eosinophil cationic protein and atopic dermatitis or allergic rhinitis in an unselected population of children, Vol.19, No.1, pp. 61-65, ISSN 0926-9959

Shin, H.D.; Park, B.L.; Kim, L.H. (2005). Allergy. Interleukin-10 haplotype associated with total serum IgE in atopic dermatitis patients, Vol.60, No.9, pp. 1146-1151, ISSN 0105-4538 
Sohn, M.H.; Lee, K.E. \& Kim, K.E. (2004). Allergy Asthma Proc. Interleukin-18 is associated with increased severity of atopic dermatitis in children, Vol.25, No.3, pp. 181-184, ISSN 1088-5412

Song, T.W.; Sohn, M.H.; Kim, E.S. (2006). Clin Exp Allergy. Increased serum thymus and activation-regulated chemokine and cutaneous T cell-attracting chemokine levels in children with atopic dermatitis, Vol.36, No.3, pp. 346-351, ISSN 0954-7894

Souwer, Y.; Szegedi, K.; Kapsenberg, M.L. (2010). Curr Opin Immunol. IL-17 and IL-22 in atopic allergic disease, Vol.22, No.6, pp. 821-826, ISSN 1879-0372

Steinhoff, M.; Bienenstock, J.; Schmelz, M. (2006). J Invest Dermatol. Neurophysiological, neuroimmunological, and neuroendocrine basis of pruritus, Vol.126, No.8, pp. 1705-1718, ISSN 0022-202X

Stromberg, L. (2002). Acta Paediatr. Diagnostic accuracy of the atopy patch test and the skinprick test for the diagnosis of food allergy in young children with atopic eczema/dermatitis syndrome, Vol.91, No.10, pp. 1044-1049, ISSN 0803-5253

Sugarman, J.L.; Fluhr, J.W.; Fowler, A.J. (2003). Arch Dermatol. The objective severity assessment of atopic dermatitis score: an objective measure using permeability barrier function and stratum corneum hydration with computer-assisted estimates for extent of disease, Vol.139, No.11, pp. 1417-1422, ISSN 0003-987X

Sugiura, H.; Umemoto, N.; Deguchi, H. (1998). Acta Derm Venereol. Prevalence of childhood and adolescent atopic dermatitis in a Japanese population: comparison with the disease frequency examined 20 years ago, Vol.78, No.4, pp. 293-294, ISSN 0001-5555

Taniuchi, S.; Chihara, J.; Kojima, T. (2001). J Dermatol Sci. Serum eosinophil derived neurotoxin may reflect more strongly disease severity in childhood atopic dermatitis than eosinophil cationic protein, Vol.26, No.1, pp. 79-82, ISSN 0923-1811

Toda, M.; Leung, D.Y.; Molet, S. (2003). J Allergy Clin Immunol. Polarized in vivo expression of IL-11 and IL-17 between acute and chronic skin lesions, Vol.111, No.4, pp. 875-881, ISSN 0091-6749

Umemoto, N.; Kakurai, M.; Okazaki, H. (2003). J Dermatol Sci. Serum levels of vasoactive intestinal peptide are elevated in patients with atopic dermatitis, Vol.31, No.2, pp. 161-164, ISSN 0923-1811

Voegeli, R.; Rawlings, A.V.; Breternitz, M. (2009). Br J Dermatol. Increased stratum corneum serine protease activity in acute eczematous atopic skin, Vol.161, No.1, pp. 70-77, ISSN 1365-2133

Wang, Y.H.; Ito, T.;Homey, B. (2006). Immunity. Maintenance and polarization of human TH2 central memory $\mathrm{T}$ cells by thymic stromal lymphopoietin-activated dendritic cells, Vol.24, No.6, pp. 827-838, ISSN 1074-7613

Whalley, D.; McKenna, S.P.; Dewar, A.L. (2004). Br J Dermatol. A new instrument for assessing quality of life in atopic dermatitis: international development of the Quality of Life Index for Atopic Dermatitis (QoLIAD), Vol.150, No.2, pp. 274-283, ISSN 0007-0963

Woessner, J.F., Jr. (2001). J Clin Invest. That impish TIMP: the tissue inhibitor of metalloproteinases-3, Vol.108, No.6, pp. 799-800, ISSN 0021-9738

Wu, K.G.; Li, T.H.; Chen, C.J. (2011). Int J Immunopathol Pharmacol. Correlations of serum Interleukin-16, total IgE, eosinophil cationic protein and total eosinophil counts 
with disease activity in children with atopic dermatitis, Vol.24, No.1, pp. 15-23, ISSN 0394-6320

Yoshizawa, Y.; Nomaguchi, H.;Izaki, S. (2002). Clin Exp Dermatol. Serum cytokine levels in atopic dermatitis, Vol.27, No.3, pp. 225-229, ISSN 0307-6938

Zhang, H.; Guo, Y.; Wang, W. (2011). Allergy. Mutations in the filaggrin gene in Han Chinese patients with atopic dermatitis, Vol.66, No.3, pp. 420-427, ISSN 1398-9995

Zlotnik, A. \& Yoshie, O. (2000). Immunity. Chemokines: a new classification system and their role in immunity, Vol.12, No.2, pp. 121-127, ISSN 1074-7613 


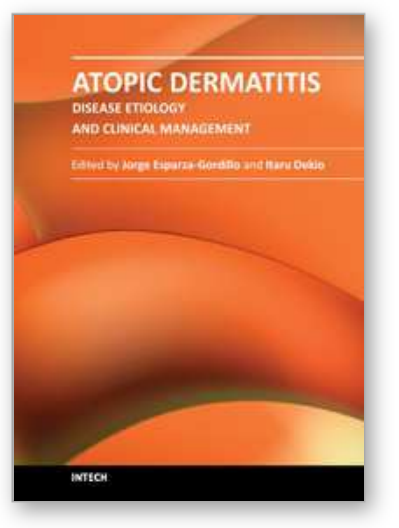

\author{
Atopic Dermatitis - Disease Etiology and Clinical Management \\ Edited by Dr. Jorge Esparza-Gordillo
}

ISBN 978-953-51-0110-9

Hard cover, 414 pages

Publisher InTech

Published online 22, February, 2012

Published in print edition February, 2012

Atopic Dermatitis is a common disease characterized by inflamed, itching and dry skin. This relapsing allergic disorder has complex etiology and shows a remarkably high clinical heterogeneity which complicates the diagnosis and clinical management. This book is divided into 4 sections. The first section (Disease Etiology) describes some of the physiological mechanisms underlying Atopic Dermatitis, including alterations in the immune system and the skin-barrier function. The important role of host-microorganism interactions on the pathophysiology of Atopic Dermatitis is discussed in the second section (Microorganisms in Atopic Dermatitis). An overview of the clinical diagnostic criteria and the disease management protocols commonly used is given in the third section (Diagnosis and Clinical Management). The last section (New Treatments) describes new therapeutic approaches that are not widely used but are currently being studied due to preliminary evidence showing a clinical benefit for Atopic Dermatitis.

\title{
How to reference
}

In order to correctly reference this scholarly work, feel free to copy and paste the following:

Zheng-Hong Di, Li Zhang, Ya-Ni Lv, Li-Ping Zhao, Hong-Duo Chen and Xing-Hua Gao (2012). Advances in Assessing the Severity of Atopic Dermatitis, Atopic Dermatitis - Disease Etiology and Clinical Management, Dr. Jorge Esparza-Gordillo (Ed.), ISBN: 978-953-51-0110-9, InTech, Available from:

http://www.intechopen.com/books/atopic-dermatitis-disease-etiology-and-clinical-management/advances-inassessing-the-severity-of-atopic-dermatitis

\section{INTECH}

open science | open minds

\section{InTech Europe}

University Campus STeP Ri

Slavka Krautzeka 83/A

51000 Rijeka, Croatia

Phone: +385 (51) 770447

Fax: +385 (51) 686166

www.intechopen.com

\section{InTech China}

Unit 405, Office Block, Hotel Equatorial Shanghai

No.65, Yan An Road (West), Shanghai, 200040, China

中国上海市延安西路65号上海国际贵都大饭店办公楼405单元

Phone: +86-21-62489820

Fax: $+86-21-62489821$ 
(C) 2012 The Author(s). Licensee IntechOpen. This is an open access article distributed under the terms of the Creative Commons Attribution 3.0 License, which permits unrestricted use, distribution, and reproduction in any medium, provided the original work is properly cited. 